\title{
Deep Skull from Niah Cave and the Pleistocene Peopling of Southeast Asia
}

\author{
Darren Curnoe ${ }^{1 *}$, Ipoi Datan ${ }^{2}$, Paul S. C. Taçon ${ }^{3}$, Charles Leh Moi Ung ${ }^{2}$ and \\ Mohammad S. Sauffi ${ }^{2}$ \\ ${ }^{1}$ Palaeontology, Geobiology and Earth Archives Research Centre, School of Biological, Earth and Environmental Sciences, \\ University of New South Wales, Sydney, NSW, Australia, ${ }^{2}$ Sarawak Museum Department, Kuching, Malaysia, ${ }^{3}$ Place, \\ Evolution and Rock Art Heritage Unit, School of Humanities, Languages and Social Science, Griffith University, Gold Coast, \\ QLD, Australia
}

\section{OPEN ACCESS}

Edited by:

K. Christopher Beard, University of Kansas, USA

Reviewed by:

Jürgen Kriwet,

University of Vienna, Austria Graeme William Barker, University of Cambridge, UK

${ }^{*}$ Correspondence: Darren Curnoe d.curnoe@unsw.edu.au

Specialty section: This article was submitted to Paleontology

a section of the journal

Frontiers in Ecology and Evolution

Received: 18 February 2016 Accepted: 08 June 2016

Published: 27 June 2016

Citation:

Curnoe D, Datan I, Taçon PSC, Leh Moi Ung C and Sauffi MS (2016) Deep Skull from Niah Cave and the Pleistocene Peopling of Southeast Asia. Front. Ecol. Evol. 4:75 doi: 10.3389/fevo.2016.00075
The Deep Skull from Niah Cave in Sarawak (Malaysia) is the oldest anatomically modern human recovered from island Southeast Asia. For more than 50 years its relevance to tracing the prehistory of the region has been controversial. The most widely held view, originating with Brothwell's 1960 description and analysis, is that the Niah individual is related to Indigenous Australians. Here we undertake a new assessment of the Deep Skull and consider its bearing on this question. In doing so, we provide a new and comprehensive description of the cranium including a reassessment of its ontogenetic age, sex, morphology, and affinities. We conclude that this individual was most likely to have been of advanced age and female, rather than an adolescent male as originally proposed. The morphological evidence strongly suggests that the Deep Skull samples the earliest modern humans to have settled Borneo, most likely originating on mainland East Asia. We also show that the affinities of the specimen are most likely to be with the contemporary indigenous people of Borneo, although, similarities to the population sometimes referred to as Philippine Negritos cannot be excluded. Finally, our research suggests that the widely supported "two-layer" hypothesis for the Pleistocene peopling of East/Southeast Asia is unlikely to apply to the earliest inhabitants of Borneo, in-line with the picture emerging from genetic studies of the contemporary people from the region.

Keywords: modern humans, Pleistocene, Southeast Asia, Australasia, Niah Cave

\section{INTRODUCTION}

Discussions about the initial settlement of Southeast Asia and Australasia by anatomically modern humans (AMH) have historically focused on evidence from a small number of Late Pleistocene human remains scattered across this broad region (Thorne et al., 1999; Dizon et al., 2002; Détroit et al., 2004; Olley et al., 2006; Barker et al., 2007, 2013; Mijares et al., 2010; Demeter et al., 2012; Storm et al., 2013). In many cases, the geological age, and sometimes even taxonomic affinity, of these ancient remains continues to be uncertain (Thorne et al., 1999; Dizon et al., 2002; Détroit et al., 2004; Olley et al., 2006; Barker et al., 2007, 2013; Mijares et al., 2010; Demeter et al., 2012; Storm et al., 2013). This only serves to confound the already complicated task of reconstructing the colonization routes and timing of the dispersal of the earliest AMH across Southeast Asia 
and Australasia as well as their possible relationships to recent populations. Still, with recent advances in dating methods, several new field discoveries, the reexamination of existing but poorly characterized remains and genetic investigations of contemporary populations (e.g., Capelli et al., 2001; Karafet et al., 2001; Hill et al., 2007; Soares et al., 2008, 2016; Tumonggor et al., 2013; Trejaut et al., 2014) it is becoming clear that the earliest AMH settled East Asia by at least $45 \mathrm{ka}$ (Mijares et al., 2010; Demeter et al., 2012; Barker et al., 2013; Hunt and Barker, 2014), and probably in the range of $80-120 \mathrm{ka}$ (Hill et al., 2007; Soares et al., 2008, 2016; Bae et al., 2014; Liu et al., 2015; Curnoe et al., 2016).

Superimposed on the Late Pleistocene history of the region are more recent prehistoric migrations by agriculturalists such as Sino-Tibetan, Tai and Austroasiatic speaking people into mainland Southeast Asia and Austronesian speakers across oceanic Southeast Asia (Bellwood, 1997). The idea that these migrations resulted in the replacement of most of the huntergatherers of the regon by Neolithic populations has been debated now for 80 years (e.g., van Stein Callenfels, 1936; Hooijer, 1950; Von Koenigswald, 1952; Brothwell, 1960; Coon, 1962; Bellwood, 1997; Matsumura and Hudson, 2005). In particular, it has been widely accepted that these Late Pleistocene to early Holocene hunter-gatherers were related to recent Indigenous Australians and New Guineans, potentially even representing the earliest AMH to have settled the region (Matsumura et al., 2008). This model, dubbed the "two-layer" hypothesis (Jacob, 1967), on account of the subsequent replacement of these hunter-gatherers by immigrant Neolithic people (Bellwood, 1997), has enjoyed somewhat of a revival of late (Matsumura et al., 2008; Oxenham and Buckley, 2016), being extended even to encompass Japan (Kaifu et al., 2011).

Notably, Krigbaum and Manser (2005) undertook a test of the two-layer hypothesis employing remains from Niah Cave (excluding the Deep Skull). Using a 3D morphometric approach, they examined facial shape in crania from pre-Neolithic and Neolithic layers of the West Mouth, comparing them to various samples from East Asia, Southeast Asia, Australia and the Pacific. Their research aimed to assess whether these temporally distinct samples from Niah Cave might represent different biological populations. The results highlighted an absence of significant differences in facial shape between samples, suggesting biological and temporal continuity between the pre-Neolithic and Neolithic people at Niah Cave, as well as hinting at possible affinities of both groups to Southeast Asian and even Polynesian groups (Krigbaum and Manser, 2005). Owing to poor preservation of the remains, however, the study included only a small sample of Niah Cave crania (n4/7) and few (mostly bilateral) landmarks (n6/8) in each analysis, making the significance of their findings difficult to establish firmly.

For more than 50 years the Deep Skull from Niah Cave (Figures 1A-K) has been a key specimen in the debate surrounding the origins of AMH in Southeast Asia as well as the two-layer hypothesis. This cranium, lacking a mandible, was recovered in 1958 at the level of 106-110 inches in a trial trench dubbed "Hell" in the West Mouth of the great Niah Cave (Gua Niah) system in Sarawak, Malaysia (Harrisson, 1967).
Soon after, a ${ }^{14} \mathrm{C}$ date on charcoal suggested a possible age of c39,600 \pm 1000 BP (GRO1339) for this partial cranium. While some researchers have raised doubts about its stratigraphic context, suggesting it may have been an intrusive burial (Bellwood, 1997; Wolpoff, 1999), recent research including detailed stratigraphic investigations, direct uranium-series dating of cranial bone and ${ }^{14} \mathrm{C}$ of charcoal from adjacent sediments has confirmed the Deep Skull to be of Late Pleistocene antiquityderiving from the period c45-39 ka and mostly likely around 37 ka (Barker et al., 2013; Hunt and Barker, 2014). Crucially, this makes the Deep Skull the earliest securely dated AMH remains in island Southeast Asia.

Brothwell (1960) has provided the only detailed, but nonetheless incomplete, description of the specimen, which was published more than 50 years ago. He tentatively reported that the cranium belonged to an adolescent (15-17 years of age), was of unknown sex, and showed strongest resemblances to Tasmanians, speculating that the Deep Skull lay within an evolutionary lineage to the "Negritoids." At the time, the Negritoid "race" was seen as one of the two founding modern human populations to have settled Southeast Asia and Australasia during the Pleistocene, the other one being the so-called "Australoids" or Australo-Melanesian people (e.g., Hooijer, 1950; Von Koenigswald, 1952). Brothwell's identification of the cranium as being of Tasmanian affinity was also premised on the assumption that Tasmanians and mainland Australians belonged to different populations, and while this was a widely held view at the time, traceable to the eighteenth and nineteenth century explorers like Cook, La Pérouse, and Labillardière (Mulvaney, 1958), it has since been discredited (e.g., Presser et al., 2002). Nonetheless, his inferences and methods were the subject of strong criticism by even his contemporaries (Macintosh, 1965; Mulvaney, 1966), a situation overlooked in recent discussions of the Deep Skull.

A small number of specialists subsequently offered opinions about the affinities of the remains, and they have been usefully summarized by Kennedy (1977) and Krigbaum and Datan (2005). Generally, disagreement over the past four decades has centered on whether:

- The Deep Skull is well enough preserved to play any role at all in discussions about Late Pleistocene human evolution in Southeast Asia (e.g., Kamminga and Wright, 1988). Although, Kennedy (1977) has noted that few workers in the past have studied the original remains, and this is largely true even until today.

- It is from an adolescent (Brothwell, 1960) or an adult (Birdsell, 1978; Krigbaum and Datan, 2005).

- The sex of the specimen is diagnosable at all, owing to its young ontogenetic age (Brothwell, 1960), or might sample a female (Birdsell, 1978).

- The Niah cranium belongs to an Australo-Melanesian population, as first proposed by Brothwell (1960), or a group more closely related to East Asians. While most researchers who have discussed the specimen have accepted Brothwell's (1960) diagnosis (e.g., Barker et al., 2007), Birdsell (1978) identified a Negrito component to its morphology, Harrisson 
A

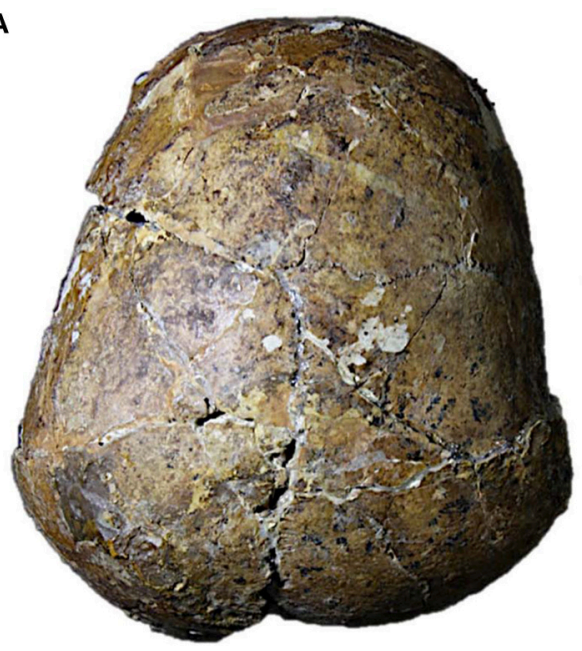

D

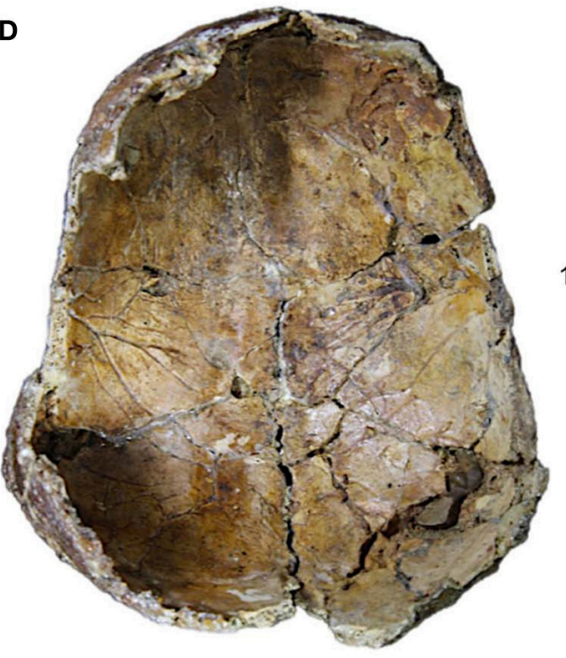

G

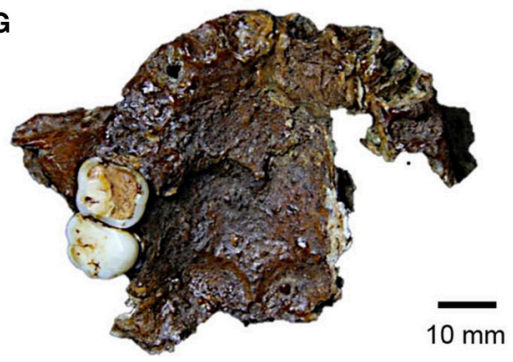

B

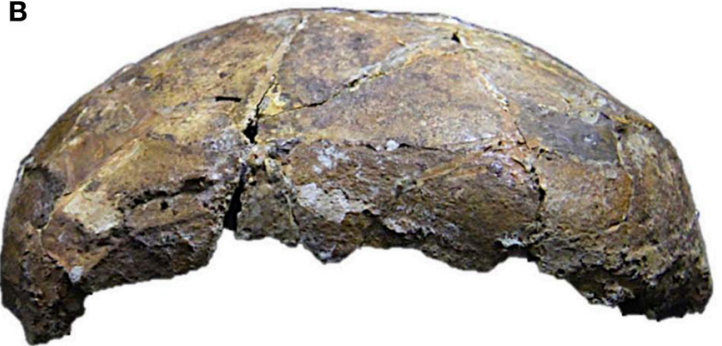

C

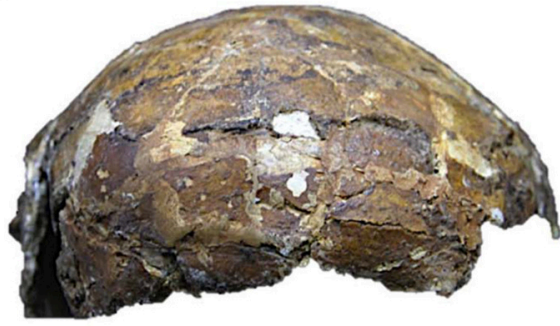

E

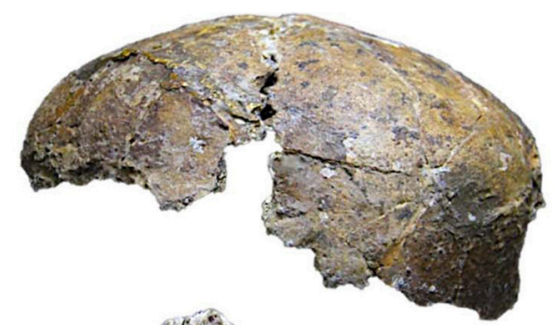

$\mathbf{F}$

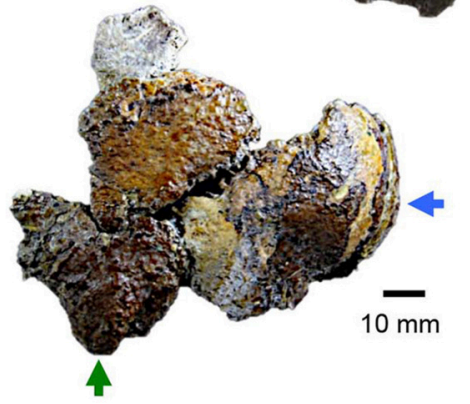

H

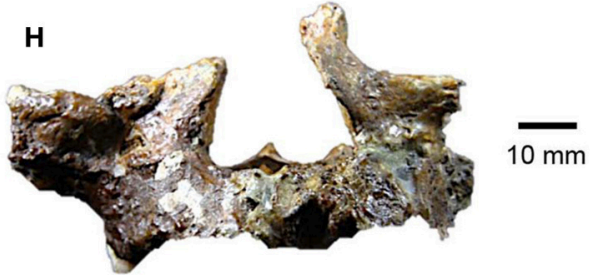

I

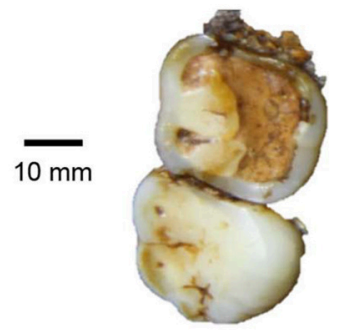

$\mathbf{J}$
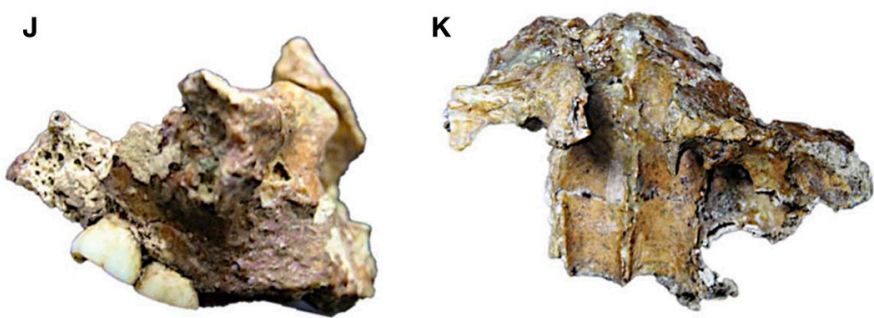

FIGURE 1 | Deep Skull from Niah Cave. Calvaria in (A) superior view, (B) left lateral view, (C) anterior view, (D) inferior/endocranial view, and (E) posterior view; (F) left isolated parieto-temporo-occipital fragment in lateral view (green arrow, mastoid process; blue arrow, occipital squama); maxilla: (G) inferior/palatal view, (H) anterior view, and (I) enlarged view of dental crowns, (J) right lateral view, and (K) superior/internal view. 
(1976) suggested it might show affinities to the contemporary Dayak people from Borneo, and Wu (1987) proposed that it belonged to a "southern Mongoloid" group that included the Austronesian speaking people inhabiting the region today. Subsequently, Wu (1992) opined that the Deep Skull was part of a wider Southeast Asian race, which has sometimes been dubbed "Malays” or "Proto-Malays" (Jacob, 1967, 1968).

It is clear, therefore, that despite its Late Pleistocene age, there is still no consensus about the importance of the Deep Skull to addressing questions surrounding the origins of $\mathrm{AMH}$ in Southeast Asia. The present study sets out to test the above issues by providing: (1) a new description of the Deep Skull including an assessment of its preservation, morphology and potential to provide metric data; (2) a reanalysis of its ontogenetic age and sex; and (3) a reconsideration of its possible affinities to Late Pleistocene/Early Holocene and recent populations from East/Southeast Asia and Australasia, with a discussion of the implications for current debates about the origins of recent populations from the region.

\section{MATERIALS AND METHODS}

Although two postcranial bones are suggested to represent the same individual as the Deep Skull (Krigbaum and Datan, 2005), our focus here is entirely on the cranial remains held by the Sarawak Museum Department in Kuching (Malaysia). All observations and measurements of the Deep Skull were made and checked by DC during 2013 and 2014. Morphological observations were also made by DC on a range of original human remains and casts including Pleistocene remains from Wadjak, Keilor, Kow Swamp, the Willandra Lakes, Zhoukoudian Upper Cave and Liujiang. Metrical data for comparative materials were taken from the literature (Von Bonin, 1931; Suzuki and Hanihara, 1982; Cuong, 1986; Brown, 1989, 2015; Storm, 1995; Wu and Poirier, 1995; Howells, 1996; Matsumura and Zuraina, 1999; Matsumura et al., 2001, 2008; Bulbeck, 2005; Green and Curnoe, 2005; Matsumura and Pookajorn, 2005; Matsumura and Hudson, 2005; Curnoe and Thorne, 2006; Demeter et al., 2012; Bae et al., 2014; Xiao et al., 2014; Liu et al., 2015) and on casts or original remains by DC.

We undertook multivariate analyses of 18 variables combining continuous and discrete (presence/absence) data. All data were log-transformed prior to analysis. We performed principal coordinates analysis and UPGMA cluster analysis employing the Gower distance using the software PAST Version 3.11 (Hammer et al., 2001).

\section{RESULTS}

\section{Developmental Age and Sex}

Brothwell (1960) reported the presence of an unerupted $\mathbf{M}^{3}$ from the Deep Skull, which was central to his diagnosis of the specimen as probably representing an adolescent (15-17 years old). Unfortunately, this tooth is not present in the collection of the Sarawak Museum Department and so could not be assessed in our study. While $\mathrm{M}^{3}$ emergence is commonly considered to be a skeletal marker of adulthood (Hillson, 1996), the failure of the $\mathrm{M}^{3} \mathrm{~s}$ to erupt is common in recent human populations, including indigenous people in Southeast Asia (Turner and Eder, 2006). Therefore, while the presence of erupted $\mathrm{M}^{3} \mathrm{~s}$ can reasonably be taken to indicate adulthood, absence, on its own, cannot be considered a reliable marker of ontogenetic age.

Several markers of developmental chronology suggest that the Deep Skull was most likely to be from an adult. First, the spheno-occipital synchondrosis is obliterated [noted also by Brothwell (1960)]. Closure of this joint in contemporary populations has been widely reported to occur on average at around 17-20 years of age (Bassed et al., 2010; Ekizoglu et al., 2016). Age estimates do, however, vary on account of sex, geographic population and method of assessment, with combined sex estimates of complete closure in the range of c1225 years old (Bassed et al., 2010; Ekizoglu et al., 2016). Thus, obliteration of the spheno-occipital synchondrosis implies an age of at least adolescence, but more likely early adulthood, in the case of the Deep Skull. Some of the vault sutures can also be assessed for closure and are characterized by advanced fusion in several locations, giving the impression that the Deep Skull is from an adult. For example, Meindel and Lovejoy's (1985) widely deployed criteria applied internally at bregma and mid-coronal (other sutures likely to be misleading owing to taphonomic damage) indicate advanced fusion (scores 2-3). Again, on its own, these are insufficient grounds to diagnose its ontogenetic age.

The degree of tooth wear seen on the Deep Skull's $\mathrm{M}^{1}$ and $\mathrm{M}^{2}$ is one of the most revealing features in terms of diagnosing its personal age. The level of occlusal wear would be large for an adolescent even among hunter-gatherers (Figure 1I). For example, applying Lovejoy's (1985) standards for age based on occlusal wear provides an estimate of 40-50 years (minimally Phase $\mathrm{H}$ ) for the Niah Cave individual's molars.

Finally, there is evidence for degenerative changes particularly on the articular surface of the mandibular fossa and the right occipital condyle possibly indicating osteoarthritis. While osteoarthritis of the temporomandibular joint is generally regarded to be a degenerative disease associated with aging, it is known clinically to occur in children and adolescents (Cho and Jung, 2012).

We conclude that while incompleteness and taphonomic damage precludes a detailed assessment of the ontogenetic age of the Deep Skull, the available evidence taken together suggests this individual was an adult at the time of death, and perhaps even one of advanced age, rather than an adolescent, as proposed by Brothwell (1960).

Regarding the sex of the Deep Skull, muscle markings are weak over the entire cranium, with very weak or absent cranial cresting. The vault shows strong bossing, and is strongly arched/rounded in each region (frontal, parietals and occipital) in all planes. Features such as the zygomatic arches are delicately built. The mastoid processes are small and weakly projecting (Figure 1F). Scores for the sexing standards of Buikstra and Ubelaker (1994) as can be applied are given in Table 1. Together, these features indicate the Deep Skull is likely to be from a female. 
TABLE 1 | Cranial sexing standards applied to the Deep Skulla.

\begin{tabular}{lc}
\hline Trait & Score \\
\hline Nuchal crest & 1 \\
Mastoid process & 1 \\
Supraorbital margin & 1 \\
Supraorbital ridge/glabella & 1
\end{tabular}

a Standards from Buikstra and Ubelaker (1994).

\section{Description and Comparison Calvaria}

In Table 2, we provide a revised list of the remaining bones of the Deep Skull as presently held by the Sarawak Museum Department. The calvaria shows signs of distortion in various places and is fragmentary (Figure 1A). The entire cranium has been coated in shellac, and in parts, Plaster of Paris has been used to fill cracks. While we agree that it may be unfossilized (see Barker et al., 2007), this would need to be confirmed with XRF or a similar analytical technique. Distortion of the calotte is at its worst on the right fronto-orbital region and right posterior parietal fragment, which have been displaced superiorly along a major crack. There is also a large crack through the middle of the left parietal, the two halves being essentially undistorted, but with the posterior half being misaligned during reconstruction. On the right side, the parietals comprise two major parts in the anteroposterior direction, the posterior part being misaligned along a common fracture with the anterior fragment.

While all of these problems lead to an exaggeration of the globularity of the vault, it is nonetheless evident that the specimen is overall very delicately built, with a strongly arched vault (sagittal and coronal planes) and sports well-developed frontal and parietal eminences. The parieto-occipital curvature is strongly vertically inclined and lacks the signs of a welldeveloped occipital bun. The largest cranial fragment from the Deep Skull has been assembled from $\sim 23$ pieces and comprises a largely complete frontal bone and much of the left and right parietals. The frontal includes a section of the right lateral orbital roof and supraorbital trigone. This region is distorted, having been displaced posteriorly and medially as a result of post-burial compression.

On the left side, a small section of the lateral roof and supraorbital margin is present: this side of the calotte is essentially undistorted. No sign of a supraorbital ridge can be discerned laterally on the right or left sides. The superciliary region is preserved on the right, but barely discernible: i.e., a very small, scarcely swollen, eminence is discoverable only through palpation. On the left, this region seems not to be preserved, being undiscernible through observation or palpation. While the glabella is incomplete, its superior half is present, but this region of the frontal lacks the inferior part and nasal root. It seems clear, however, that glabella was very weakly developed, in-line with the poorly defined superciliary ridges and evidently thin supraorbital trigones. The anterior-most part of the frontal squama bulges (swollen in appearance) for its anterior most third. It then curves evenly back to bregma, the vault being highly rounded and arched. On the right side, a prominent frontal boss
TABLE 2 | Fragments belonging to the Deep Skull held by the Sarawak Museum.

- Calvaria comprising frontal, and left and right parietal fragments.

- Temporo-occipital-sphenoid fragment: comprising left (petrous) and right temporal (petrous, part of squama and mandibular fossa) bones, basioccipital fragment, and right fragment of greater wing.

- Parieto-occipito-temporal fragment (left side): with posteroinferior parietal squama, occipital plane and some of the nuchal plane, and left temporal squama and mastoid part with mastoid process.

- Isolated fragment of probable temporal bone.

- Zygomatic bone (right, largely complete).

- Maxilla with $\mathrm{M}^{1}$ and $\mathrm{M}^{2}$.

- Frontal fragment: cast IA.

- Frontal fragment: cast IB.

- Temporo-sphenoid fragment.

- Temporal fragment: mastoid process.

- Temporal fragment: zygomatic process.

- Spheno-frontal fragment.

- Probable sphenoid fragment (sphenoid fragment \#3).

- Probable sphenoid fragment (sphenoid fragment \#4).

- Occipital fragment (left side, fragment \#1).

- Occipital fragment (left side, fragment \#2).

- Occipital fragment (right side).

- Temporal fragment: cast II.

- Ethmoid fragment (cribriform plate).

- Vomer fragment.

- Cranial fragments held together by matrix (parietal and ?temporal).

- Unidentified fragment, probably basicranial fragment.

- Bag of 9 "doubtful" fragments.

is notable. No frontal keeling can be discerned, but the region straddling the sagittal suture is slightly swollen or "heaped up." Left and right temporal crests are present, but poorly defined along most of their course, indicating weak scarring associated with the temporal muscles. The temporal fossae are moderately shallow in keeping with its overall size: i.e., the cranium has little postorbital constriction of the frontal. Viewed posteriorly, the walls are highly divergent superiorly with the parietal bosses strongly overhanging the inferior, or parieto-temporal, regions.

The parietals are short and strongly arched posteriorly in both the sagittal and transverse planes: i.e., they form a distinct and more or less vertical plane in their posterior one-third rather than bulging posteriorly (Figures 1A-E). The denticulations of the lambdoid suture are discernible and deeply invested on the right side along the suture's medial two-thirds. The occipital was evidently tall, narrow, and widely peaked, but the position of lambda cannot be accurately determined.

A second reconstructed vault fragment from the left side comprises a posteroinferior piece of the parietal squama, part of the occipital plane and some of the nuchal plane, left temporal squama and mastoid part with mastoid process (Figure 1F). The restoration is problematic in part due to difficulties ensuing from post-burial distortion. The occipital fragment lacks an external occipital protuberance or crest/torus and is without clear evidence of muscle markings. The occipital plane itself is rounded, evidently deviating little beyond the lambdoid suture 
above. Inferiorly, it is strongly undercut by a stepped nuchal plane that bulges (curves inferiorly) markedly at the first step; the second step being more or less horizontal and approaching the cranial base proper (i.e., vicinity of the foramen magnum region).

Viewed superiorly, the calotte is broadly ovoid in outline, but much wider biparietally than across the frontal (Figures 1A,C). The remaining vault gives the impression that the complete skull would have been overall quite tall, especially height to bregma, of moderate length, and relatively broad. Brothwell (1960) collected several cranial measurements on the specimen, and we have re-taken some of them, and also measured others that were available (Tables 3, 4). Maximum cranial length (GOL) was estimated by refitting the main occipital fragment to the remaining calotte. It was reconstructed by us to be moderate at $\mathrm{c} 175 \mathrm{~mm}$, a value differing by $<3 \%$ from Brothwell's (1960) estimate. Placing this within a broader geographic context, the Deep Skull is likely to have been short, its reconstructed value sitting outside of (below) the range of Pleistocene/Early Holocene Southeast Asian and Australian samples (Table 3).

Maximum cranial breadth (XCB) is positioned high on the parietals and is reconstructed by us to have been wide at c145 mm, although, this value is likely to have been affected to some extent by post-burial distortion. Still, our estimate differs from Brothwell's (1960) determination by $<4 \%$, confirming its precision. It suggests that the Deep Skull would have been a broad calvaria compared to Pleistocene/Early Holocene samples and most recent human samples, its value sitting outside of the ranges of recent Tolai and Australians (Table 3).

Reconstructed cranial index of the Deep Skull is very high at $\mathrm{c} 83 \%$ and suggests its shape may have been brachycephalic. On average, all of the Pleistocene/Early Holocene samples are mesocephalic (East and Southeast Asian) or dolichocephalic (Australian), with the Deep Skull sitting above the maximum value for all fossil sample ranges (Table 3). Moreover, the reconstructed value for the Niah specimen lies outside of the ranges of several recent samples including Tolai, Australians and Tasmanians (Table 3).

Maximum frontal breadth of the Deep Skull is reconstructed to have been moderate at $\mathrm{c} 118 \mathrm{~mm}$, however, this measurement was not recorded by Brothwell (1960). Its value sits below the minimum for both Pleistocene/Early Holocene East Asian and Southeast Asian samples (Table 4). It is, however, well within the range of Pleistocene/Early Holocene Australians, and similar to many recent populations (Table 4). An index of frontal shape (XFB/GOL) suggests the Deep Skull, at c67\%, possessed a frontal of moderate width. The estimate for the Deep Skull is outside of the range of Pleistocene/Early Holocene East Asian and Australian samples (Table 4), but is close to the average for Pleistocene/Early Holocene Southeast Asians, and well within the range of a number of recent samples excepting Australians and Tasmanians (Table 4).

As nasion is not preserved on the Deep Skull it is not possible to provide an estimate of frontal length. However, frontal length represented by the glabella-bregma chord $(\mathrm{c} 109 \mathrm{~mm})$ is estimated to be identical to the Pleistocene Chinese partial cranium from Huanglong, and within the range of Pleistocene/Early
Holocene Australians, recent Chinese and recent Australian samples (Table 4).

Endocranially, the superior sagittal sinus is poorly developed, but the frontal crest is damaged and its size cannot be reliably determined (Figure 1D). The middle meningeal vessel impressions are not large/deep, but are elaborate, being highly arborized as expected for an AMH cranium (Figure 1D). There are two large impressions of arachnoid granulations on the right side posterior to the coronal suture-they have not eroded the tabular bone though-and straddle a poorly defined superior sagittal sinus. In the case of the left coronal, swelling corresponds to an endocranial impression probably left by either a giant arachnoid granulation, or more likely, a meningeal or cerebral tumor. The ectocranial impression of this likely pathological feature could represent either ectocranial remodeling in response to pressure when the vault was developing, or perhaps resulted from lesioning and remodeling of the diploe associated with a haemoglobinopathy. The endocranial table is missing, exposing cortical bone where the frontal sinus would reside, and there seems to have a very small or even absence of a frontal sinus in the Deep Skull.

\section{Vault Thickness}

Vault thickness can be determined at a number of locations on the Deep Skull, and in Table 5 we provide and compare data at two commonly compared locations (not recorded by Brothwell). Thickness at bregma is very thin at $4.4 \mathrm{~mm}$, with the specimen siting below the minimum of Pleistocene/Early Holocene East Asian and Australian and Chinese Neolithic samples (Table 5). Among recent populations, its value is also small, but sits within their ranges (Table 5). Thickness at the parietal eminence is also thin at $4.5 \mathrm{~mm}$, again sitting outside of the Pleistocene/Early Holocene East Asian and Australian ranges, but within the thinly vaulted Jomon and Chinese Neolithic sample ranges (Table 5). Among recent humans, its value lies within all sample ranges (Table 5).

\section{Isolated Vault Fragments}

Three additional fragments of the temporals exist. These include a left fragment preserving the root of zygomatic process, with a small (narrow) temporal gutter ( $8.9 \mathrm{~mm}$ wide), the basal margin of the temporal squama, an incomplete mandibular fossa with a relatively large articular eminence, but lacking the postglenoid process and external acoustic meatus. Foramen spinosum is complete and sits within an elevated spine, and medially the foramen ovale is preserved in its lateral section only. The temporosphenoid suture is discernible. The mandibular fossa seems to be completely housed within the temporal. The mostly complete, but isolated (detached), right mastoid process is preserved. It has a small volume, is superoinferiorly short, and would have barely projected beyond the cranial base. The supramastoid crest is very weak. On the right side, the zygomatic process of the temporal is preserved, and this fragment seems to match the isolated temporo-occipital-sphenoid fragment described above. The zygomatic process is rather thin and gracile, but does curve outwards in a way that suggests the temporal 
TABLE 3 | Comparison of overall cranial length, breadth and shape (numbers in bold, where Deep Skull lies outside of sample range).

\begin{tabular}{|c|c|c|c|c|c|c|c|c|c|c|c|c|}
\hline & \multicolumn{4}{|c|}{ Maximum cranial length (GOL) (mm) } & \multicolumn{4}{|c|}{ Maximum cranial breadth $(\mathrm{XCB})(\mathrm{mm})$} & \multicolumn{4}{|c|}{ Cranial index (XCB/GOL) (\%) } \\
\hline & $n$ & Avg & $S D$ & Range & $n$ & Avg & $S D$ & Range & $n$ & Avg & $S D$ & Range \\
\hline Deep Skull & & (c175) & & & & (c145) & & & & (c83) & & \\
\hline \multicolumn{13}{|c|}{ PLEISTOCENE/EARLY HOLOCENE } \\
\hline Pooled East/Southeast Asian & 12 & 184 & 11.5 & 166-204 & 13 & 137 & 7.2 & $126-151$ & 12 & 75 & 4.2 & $70-81$ \\
\hline East Asian & 8 & 181 & 12.1 & $166-204$ & 8 & 138 & 6.1 & $131-148$ & 8 & 77 & 4.1 & $70-81$ \\
\hline Southeast Asian & 4 & 190 & 8.3 & $181-200$ & 5 & 136 & 9.4 & $126-151$ & 4 & 72 & 2.5 & 70-76 \\
\hline Australian & 44 & 194 & 9.0 & $176-220$ & 7 & 138 & 9.8 & $126-151$ & 7 & 69 & 3.0 & $65-74$ \\
\hline \multicolumn{13}{|l|}{ RECENT POPULATIONS } \\
\hline Eskimo & 108 & 185 & 6.5 & 173-206 & 108 & 133 & 4.7 & $120-142$ & 108 & 72 & 3.0 & $64-79$ \\
\hline Buriat & 109 & 177 & 7.7 & $158-194$ & 109 & 152 & 6.8 & $138-167$ & 109 & 86 & 3.7 & $77-94$ \\
\hline Ainu & 86 & 185 & 7.6 & $168-201$ & 86 & 140 & 4.9 & $130-156$ & 86 & 76 & 2.3 & $70-82$ \\
\hline Northern Japan & 87 & 179 & 8.5 & 157-195 & 87 & 139 & 5.9 & $124-152$ & 87 & 78 & 3.4 & $71-88$ \\
\hline Southern Japan & 91 & 177 & 7.1 & $162-192$ & 91 & 136 & 4.9 & $125-152$ & 91 & 77 & 3.5 & $70-89$ \\
\hline Anyang & 42 & 181 & 4.3 & $171-190$ & 42 & 139 & 5.4 & $127-151$ & 42 & 77 & 3.5 & 69-84 \\
\hline Hainan & 83 & 174 & 6.6 & $160-189$ & 83 & 137 & 4.8 & $125-149$ & 83 & 79 & 3.6 & $70-88$ \\
\hline Atayal & 47 & 174 & 6.9 & $161-190$ & 47 & 134 & 4.7 & $126-142$ & 47 & 77 & 3.1 & $70-84$ \\
\hline Philippines & 50 & 177 & 6.9 & 162-192 & 50 & 140 & 5.6 & $126-152$ & 50 & 79 & 4.0 & $67-85$ \\
\hline Aeta & 47 & 168 & 7.3 & $146-182$ & 47 & 141 & 6.1 & $118-151$ & 47 & 84 & 2.9 & 78-90 \\
\hline Dayak & 82 & 176 & 5.4 & $166-189$ & 80 & 138 & 6.0 & $123-152$ & 80 & 78 & 4.2 & $70-87$ \\
\hline Java & 203 & 172 & 7.5 & 155-200 & 203 & 142 & 5.5 & $128-163$ & 203 & 83 & 4.2 & 71-95 \\
\hline Andaman Islands & 75 & 165 & 5.3 & $153-175$ & 79 & 135 & 4.8 & $122-146$ & 75 & 82 & 2.8 & $74-89$ \\
\hline Tolai & 110 & 179 & 6.9 & 164-196 & 110 & 129 & 4.4 & $120-139$ & 110 & 72 & 2.8 & $65-80$ \\
\hline Australian & 101 & 186 & 7.5 & $169-201$ & 101 & 130 & 5.4 & $117-144$ & 101 & 70 & 2.5 & 63-77 \\
\hline Tasmanian & 87 & 182 & 6.9 & 164-203 & 87 & 136 & 6.1 & $118-149$ & 87 & 75 & 2.7 & $68-80$ \\
\hline
\end{tabular}

muscles may have been quite well developed (somewhat flaring arches).

The basioccipital clivus is small, being anteroposteriorly short and mediolaterally narrow. The pharyngeal tubercle is barely discernible. This fragment preserves the anterior margin of the foramen magnum which, judging by its curvature, would have been narrow. The sphenoidal sinus is not preserved. The right petrous is strongly angled sagittally, while the left petrous retains the broken base of a small styloid process. The stylomastoid foramen is located lateral and slightly posterior to the process. The petrous crest is very tall, sharp and laterally extensive, passing to meet the base of the acoustic part. It is superoinferiorly tall and anteroposteriorly very narrow. The opening of the carotid canal is well preserved while the cochlear aquaduct is large. Internally, the region around and including the internal acoustic meatus and pertous pyramid are well preserved. The arcuate eminence is very distinct. On the right side, the base of the mastoid process is preserved (mastoid pr. broken away); with the digastric fossa preserved anteriorly. The external acoustic meatus has broken away from the styloid process laterally. The carotid canal is clear.

The floor of the right mandibular fossa of the Deep Skull is a deep rectangle, being bounded on three sides. It has been modified probably as result of osteoarthritis, an observation supported by apparent pitting on its roof. The principal dimensions (not recorded by Brothwell) of the mandibular fossa are: chord length $16.3 / 13.1 \mathrm{~mm}(\mathrm{r} / \mathrm{l})$, breadth $35 \mathrm{~mm}$ (l), and depth c5.0/4.0 mm (r/l). Few comparable measurements are available in the literature, however, this feature has been studied in Pleistocene/Early Holocene Australians and they differ significantly from the morphology seen in the Deep Skull: the mandibular fossa of the Niah specimen is strikingly short (Australian: n7, Avg. $29.6 \mathrm{~mm}$, SD $2.8 \mathrm{~mm}$, range $26-33 \mathrm{~mm}$ ) and broad (Australian: n10, Avg. $29.9 \mathrm{~mm}$, SD $6.3 \mathrm{~mm}$, range 19.8-38.7 mm), but with a depth similar to that typically seen among Pleistocene/Early Holocene Australians (Australian: n11, Avg. $4.8 \mathrm{~mm}$, SD $1.5 \mathrm{~mm}$, range $1.5-7.0 \mathrm{~mm}$ ). The pre-glenoid plane rises steeply from the articular eminence at an angle of c45 degrees.

The articular eminence is itself large and well demarcated from the surrounding bone. The postglenoid process is damaged (fragmented and missing its medial half), but was evidently small. Endocranially, the internal acoustic meatus is well preserved, as is the entire medial wall of the petrous part. The arcuate eminence is very distinct, being larger than the left side. The petrosquamosal surface is also preserved. A shallow sigmoid sinus is evident.

The right sphenoid fragment comprises part of the greater wing through to the carotid groove medially. Foramen ovale is present. Part of the sphenoid sinus is visible. Endocranially, the bone surface is mostly broken away above the mastoid part exposing large air cells down into the mastoid process. The internal occipital protuberance is preserved and retains the left transverse sinus, which is shallow. There is a lump of heavily 
TABLE 4 | Comparison of frontal size and shape (numbers in bold, where Deep Skull lies outside of sample range).

\begin{tabular}{|c|c|c|c|c|c|c|c|c|c|c|c|c|}
\hline & \multicolumn{4}{|c|}{ Maximum frontal breadth (XFB) (mm) } & \multicolumn{4}{|c|}{ Frontal shape index 1 (XFB/GOL) (\%) } & \multicolumn{4}{|c|}{ Frontal length (GBL) (mm) } \\
\hline & $n$ & Avg & $S D$ & Range & $n$ & Avg & $S D$ & Range & $n$ & Avg & $S D$ & Range \\
\hline Deep Skull & & (c118) & & & & $(\mathrm{c} 67)$ & & & & c109 & & \\
\hline \multicolumn{13}{|c|}{ PLEISTOCENE/EARLY HOLOCENE } \\
\hline Pooled East/Southeast Asian & 5 & 121 & 7.0 & $112-129$ & 12 & 73 & 7.0 & 59-81 & - & - & - & - \\
\hline East Asian & 3 & 126 & 2.0 & $125-129$ & 8 & 77 & 4.1 & $70-81$ & 1 & 109 & - & - \\
\hline Southeast Asian & 2 & 113.5 & - & $112-115$ & 4 & 66 & 6.3 & 59-73 & - & - & - & - \\
\hline Australian & 5 & 111 & 7.0 & $105-121$ & 5 & 58 & 3.8 & $53-61$ & 42 & 116 & 7.2 & $97-134$ \\
\hline \multicolumn{13}{|l|}{ RECENT POPULATIONS } \\
\hline Eskimo & 108 & 111 & 4.3 & $100-122$ & 108 & 60 & 2.6 & $55-67$ & - & - & - & - \\
\hline Buriat & 109 & 124 & 5.9 & $112-145$ & 109 & 70 & 3.3 & 63-78 & - & - & - & - \\
\hline Ainu & 86 & 118 & 4.7 & $105-127$ & 86 & 64 & 2.1 & 59-69 & - & - & - & - \\
\hline Northern Japan & 87 & 114 & 5.6 & $102-127$ & 87 & 64 & 3.0 & $57-73$ & - & - & - & - \\
\hline Southern Japan & 91 & 113 & 4.7 & $102-122$ & 91 & 64 & 2.9 & $58-73$ & - & - & - & - \\
\hline Chinese & - & - & - & - & - & - & - & - & 65 & 107 & 5.7 & $90-120$ \\
\hline Anyang & 42 & 115 & 5.0 & $104-127$ & 42 & 64 & 3.2 & $57-70$ & - & - & - & - \\
\hline Hainan & 83 & 113 & 5.2 & $101-127$ & 83 & 65 & 3.3 & $58-74$ & - & - & - & - \\
\hline Atayal & 47 & 112 & 4.5 & $101-122$ & 47 & 64 & 2.2 & 60-69 & - & - & - & - \\
\hline Philippines & 50 & 115 & 4.7 & $104-125$ & 50 & 65 & 3.3 & $57-72$ & - & - & - & - \\
\hline Dayak & 7 & 113 & 8.6 & $100-125$ & 7 & 62 & 6.3 & 54-68 & 7 & 106 & 9.1 & $97-119$ \\
\hline Andaman Islands & 70 & 108 & 5.1 & $97-120$ & 70 & 66 & 2.5 & $61-72$ & - & - & - & - \\
\hline Tolai & 110 & 108 & 4.0 & $97-119$ & 106 & 61 & 2.5 & 54-68 & - & - & - & - \\
\hline Australian & 96 & 108 & 4.3 & $96-119$ & 101 & 58 & 2.3 & 53-64 & 100 & 106 & 4.2 & $94-119$ \\
\hline Tasmanian & 95 & 110 & 5.4 & $95-122$ & 87 & 61 & 2.7 & 53-67 & - & - & - & - \\
\hline
\end{tabular}

TABLE 5 | Vault thickness compared (numbers in bold, where Deep Skull lies outside of sample range).

\begin{tabular}{|c|c|c|c|c|c|c|c|c|}
\hline & \multicolumn{4}{|c|}{ Bregma (mm) } & \multicolumn{4}{|c|}{ Parietal Eminence (mm) } \\
\hline & $n$ & Avg & $S D$ & Range & $n$ & Avg & $S D$ & Range \\
\hline Deep Skull & & 4.4 & & & & 4.5 & & \\
\hline \multicolumn{9}{|l|}{ PLEISTOCENE/HOLOCENE } \\
\hline Pooled East/Southeast Asian & 8 & 9.7 & 2.7 & $6.0-12.5$ & - & - & - & - \\
\hline East Asian & 7 & 10.1 & 3.0 & $6.0-12.5$ & 3 & 7.3 & 1.0 & $6.5-8.5$ \\
\hline Southeast Asian & 1 & 8.0 & - & - & - & - & - & - \\
\hline Australian & 35 & 10.2 & 2.3 & $6.1-17.2$ & 30 & 7.8 & 2.1 & $5.3-14.0$ \\
\hline Jomon & 44 & 8.4 & 1.6 & $3.7-13.1$ & 47 & 6.4 & 1.5 & $2.0-10.8$ \\
\hline Chinese Neolithic & 176 & 7.6 & 1.6 & $4.7-13.8$ & 189 & 5.8 & 1.3 & $3.4-9.5$ \\
\hline \multicolumn{9}{|l|}{ RECENT POPULATIONS } \\
\hline Japanese & 152 & 6.2 & 1.2 & $2.5-9.9$ & 152 & 5.1 & 1.2 & $1.5-8.6$ \\
\hline Chinese & 73 & 7.0 & 1.4 & $4.0-10.6$ & 62 & 6.4 & 1.4 & $4.0-10.0$ \\
\hline Murray Valley & 124 & 7.7 & 1.5 & $4.0-12.6$ & 110 & 6.4 & 1.4 & $3.2-10.8$ \\
\hline
\end{tabular}

glued bone comprising multiple fragments of cancellous bone sitting above, within the occipital sulcus, which is clearly not in its anatomically correct location. The cerebral fossae are small. The temporal squama fragment sports two impressions of blood vessels (middle meningeal grooves), which are moderately incised.

Three further occipital fragments remain: the first is from the left side and contains the occipital condyle and, unusually, a bifurcated hypoglossal canal (thick and mediolaterally continuous bony septum bifurcating the canal). The condyle is $26 \mathrm{~mm}$ in anteroposterior length, and $12 \mathrm{~mm}$ at its maximum mediolateral width. Thus, it is long and slender. The second fragment comprises the posterior, left lateral, margin of the foramen magnum and nuchal plane with internal occipital crest. It should match the left occipital fragment with condyle, but no obvious articulation is observable, with intervening bone missing. Estimated maximum width of the foramen magnum is $\mathrm{c} 20 \mathrm{~mm}$. The third fragment is from the right side and comprises 
the anterior margin of the foramen magnum to the median sagittal plane (including basion) and an incomplete occipital condyle. The hypoglossal canal is a single and relatively small foramen.

\section{Zygomatic}

A right zygomatic fragment exists and it comprises the frontal process, partial temporal process and most of the body. The inferior rim is broken away anteriorly so that neither the masseteric attachment nor the tubercle are preserved. This fragment does not articulate with the calvaria in any obvious way. It may fit onto the maxilla, but again any possible contacts are unclear. Overall, the zygomatic is superoinferiorly short, but it is surprisingly robust with a thick (anteroposteriorly long) lateral orbital pillar (frontal process), combined with what must have been a thin temporal process. The superoinferior height of the zygomatic, from zygomatico-frontal suture vertically down to the inferior margin, is $32 \mathrm{~mm}$.

\section{Maxilla}

The maxillary fragment comprises much of the body; with left frontal process, medial inferior rim of the left orbit and much of the inferior orbital rim right side; right zygomatic process; inferior piriform (nasal) aperture and much of the floor of the cavity; alveolar process; roof of the palate with palatine processes and incomplete perpendicular plates of ethmoid; foramina likely preserved but obscured by shallac; and right $\mathrm{I}^{1}-\mathrm{P}^{2}$ alveoli, right
$\mathrm{M}^{1}-\mathrm{M}^{2}$ crowns, and on the left the $\mathrm{I}^{1}-\mathrm{P}^{1}$ and partial $\mathrm{P}^{2}$ alveoli (Figures 1G,I).

The anterior margin of the zygomatic process of the maxilla arises from above $\mathrm{P}^{2} / \mathrm{M}^{1}$. The lower and mid-face are flat while the canine fossa is trace only. Minimum cheek height (WMH) in the Deep Skull is estimated to be short at c20.0 $\mathrm{mm}$ (dimension not recorded by Brothwell). Unfortunately, only data employing Martin's 48(d) for East/Southeast Asian and ancient Australians are available in the literature limiting our comparisons. Still, $\mathrm{WMH}$ is short by recent human standards, being identical to average values for the Australian and Tasmanian samples, and well within the range of most recent human samples (Table 6).

The left lateral nasal margin/zygomatic process has not been fitted correctly. It has been rotated too far medially and should be positioned in a more upright position (vertically). Only the anterior margins of the orbital floors are preserved. The entry into the nasal cavity is a gentle slope. A broad, flat and bifid anterior nasal spine sits just outside of (anterior to) the nasal aperture. It is flat and relatively indistinct from the nasal border. On the right side, there are two crests that begin at the corner of the aperture, one coursing anteromedially to the nasal spine (spinal crest), more or less horizontally and demarcating the entrance to the cavity as a small sharp crest; the other coursing inferomedially onto the nasoalveolar clivus to the inferior part of the anterior nasal spine (turbinal crest). A shallow and narrow sill sits between them.

TABLE 6 | Comparison of maxillary dimensions (numbers in bold, where Deep Skull lies outside of sample range).

\begin{tabular}{|c|c|c|c|c|c|c|c|c|}
\hline & \multicolumn{4}{|c|}{ Cheek Height (WMH) (mm) } & \multicolumn{4}{|c|}{ Nasal Breadth (NLB) (mm) } \\
\hline & $n$ & Avg & $S D$ & Range & $n$ & Avg & $S D$ & Range \\
\hline Deep Skull & & c20 & & & & 29 & & \\
\hline \multicolumn{9}{|c|}{ PLEISTOCENE/EARLY HOLOCENE } \\
\hline Pooled East/Southeast Asian & - & - & - & - & 11 & 28 & 2.0 & $24-32$ \\
\hline East Asian & - & - & - & - & 5 & 27 & 3.0 & $24-32$ \\
\hline Southeast Asian & - & - & - & - & 6 & 28 & 1.0 & $26-30$ \\
\hline Australian & - & - & - & - & 36 & 29 & 2.6 & $18-32$ \\
\hline \multicolumn{9}{|l|}{ RECENT POPULATIONS } \\
\hline Eskimo & 108 & 25 & 2.4 & 19-31 & 108 & 24 & 1.6 & $20-29$ \\
\hline Buriat & 109 & 28 & 2.5 & 23-35 & 109 & 28 & 2.1 & 22-34 \\
\hline Ainu & 86 & 23 & 2.4 & $19-31$ & 86 & 27 & 2.1 & 23-32 \\
\hline Northern Japan & 87 & 23 & 2.5 & $18-30$ & 87 & 26 & 1.8 & $21-32$ \\
\hline Southern Japan & 91 & 23 & 2.8 & $16-30$ & 91 & 26 & 1.7 & $21-31$ \\
\hline Anyang & 42 & 27 & 2.1 & $21-30$ & 42 & 28 & 2.1 & 23-33 \\
\hline Hainan & 83 & 25 & 2.0 & 19-29 & 83 & 27 & 2.1 & 21-31 \\
\hline Atayal & 47 & 21 & 2.3 & $16-27$ & 47 & 26 & 2.0 & 23-31 \\
\hline Philippines & 50 & 23 & 2.3 & $15-28$ & 50 & 28 & 1.6 & $26-32$ \\
\hline Aeta & - & - & - & - & 75 & 27 & 2.1 & $21-31$ \\
\hline Dayak & - & - & - & - & 77 & 25 & 2.9 & $13-34$ \\
\hline Java & - & - & - & - & 203 & 27 & 1.7 & 23-32 \\
\hline Andaman Islands & 70 & 19 & 1.8 & $16-23$ & 70 & 24 & 1.6 & $21-29$ \\
\hline Tolai & 110 & 22 & 2.4 & $14-28$ & 110 & 27 & 1.9 & 23-32 \\
\hline Australian & 101 & 20 & 2.3 & $16-27$ & 101 & 27 & 1.8 & 23-34 \\
\hline Tasmanian & 87 & 20 & 2.0 & $16-25$ & 87 & 28 & 2.1 & 24-34 \\
\hline
\end{tabular}


TABLE 7 | Molar crown buccolingual diameters compared.

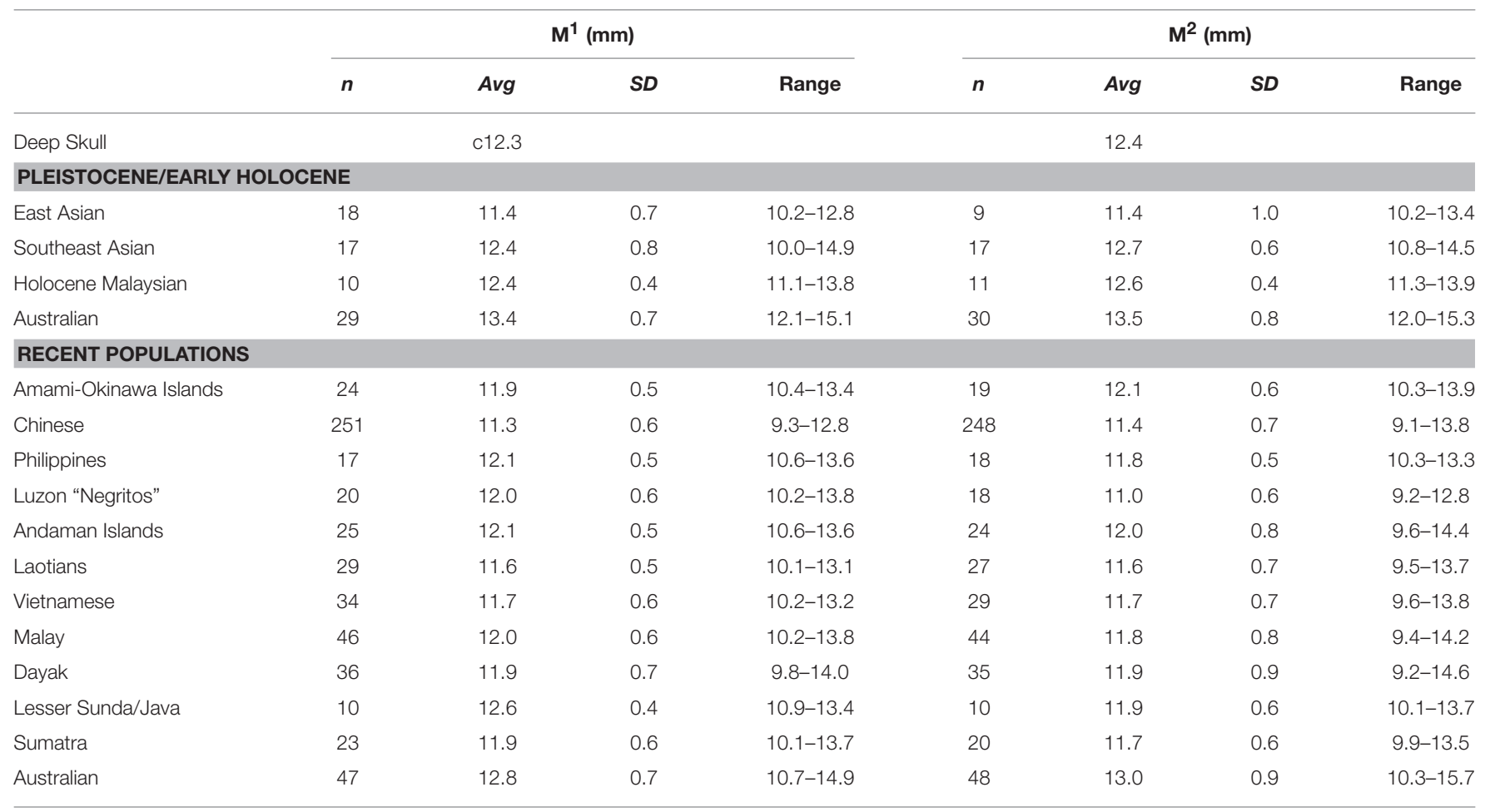

The piriform aperture of the Deep Skull is broad at $29 \mathrm{~mm}$ ( $<3 \%$ different to Brothwell's estimate) (Table 6). This value sits within the range of all comparative samples and is identical to the Pleistocene/Early Holocene Australian average (Table 6). The nasoalveolar height (nasospinale-prosthion) is $13.3 \mathrm{~mm}$ in the Deep Skull, which is short compared with samples of Pleistocene/Early Holocene Australians (n32, Avg. 20.2 mm, SD $3.1 \mathrm{~mm}$, range $13-27 \mathrm{~mm}$ ), and the Late Pleistocene Chinese Zhoukoudian Upper Cave $101(18 \mathrm{~mm})$ and Liujiang $(20 \mathrm{~mm})$ crania. However, it does lie within the range of Neolithic Chinese (n178, Avg. $20.0 \mathrm{~mm}$, SD $2.7 \mathrm{~mm}$, range 12-28 mm) and recent Chinese (n63, Avg. $19.3 \mathrm{~mm}$, SD $2.5 \mathrm{~mm}$, range $12-26 \mathrm{~mm}$ ) samples (dimension not recorded by Brothwell).

The anterior margin of the dental arcade is evenly arched and projects only slightly forward of the face with the anterior tooth roots sitting forward of a line projected inferiorly from the anterior nasal margin (i.e., low alveolar prognathism) (Figures 1G,H,J,K). Palate length and breadth cannot be accurately estimated, but palate height is reconstructed to be $\mathrm{c} 11 \mathrm{~mm}$ at the level of the $\mathrm{M}^{1} \mathrm{~s}$ (not taken by Brothwell). Thus, the palate of the Deep Skull is shallow compared with Gua Gunung $(16 \mathrm{~mm})$ and Moh Kiew $(17 \mathrm{~mm})$, but is within the range of Pleistocene/Early Holocene Australians (n10, Avg. $15 \mathrm{~mm}$, SD $5.8 \mathrm{~mm}$, Range c7-23 mm) and similar to crania from Zhoukoudian Upper Cave $(9-13 \mathrm{~mm})$ and Liujiang $(9.5 \mathrm{~mm})$. Its value is also similar to sample average for recent Japanese (n71, Avg. $11.4 \mathrm{~mm}$, SD $2.7 \mathrm{~mm}$ ) and Australians (n73, Avg. $11.5 \mathrm{~mm}$, SD $2.1 \mathrm{~mm}$ ). The Deep Skull also sports a palatine torus.

\section{Dentition}

The occlusal surface of the $\mathrm{M}^{1}$ crown is heavily worn; well into the dentine lingually; while buccally it shows wear into the dentine exposed as "eyes" in the enamel over cusp apices (Figures 1G-I). The $\mathrm{M}^{2}$ lacks interstitial wear distally suggesting the missing $\mathrm{M}^{3} \mathrm{~s}$ had not erupted (see above). It shows advanced wear on its crown, especially the buccal half where it has worn well into the dentine, seen as a mesiodistally long groove. Applying Smith (1984) scheme results in estimates of very advanced wear for both teeth: Stages 5/6 (see also, above).

Table 7 lists and compares buccolingual (BL) dimensions for the maxillary molars. The Deep Skull's $\mathrm{M}^{1}$ crown is moderate in size (c12.3 mm; identical to Brothwell's estimate), being closest to the average for Pleistocene/Early Holocene Southeast Asian and Holocene Malaysian crowns, smaller than Australians, but well within the range of all other samples (Table 7). Among recent human samples, the Deep Skull $\mathrm{M}^{1}$ crown is most similar to southern Southeast Asian samples and the Andaman Islands, but also well within the range of all other samples (Table 7). Thus, it shows no clear affinity with any of the samples given in Table 7. The Deep Skull $\mathrm{M}^{2}$ crown BL (12.4 mm; 4.5\% different to Brothwell's estimate) is again moderate in size, being closest to the average for Pleistocene/Early Holocene Southeast Asian and Holocene (Peninsula) Malaysian samples, but smaller than Australians (Table 7). Its value sits within the range of all Pleistocene/early Holocene and recent samples and again shows no clear affinities (Table 7). 


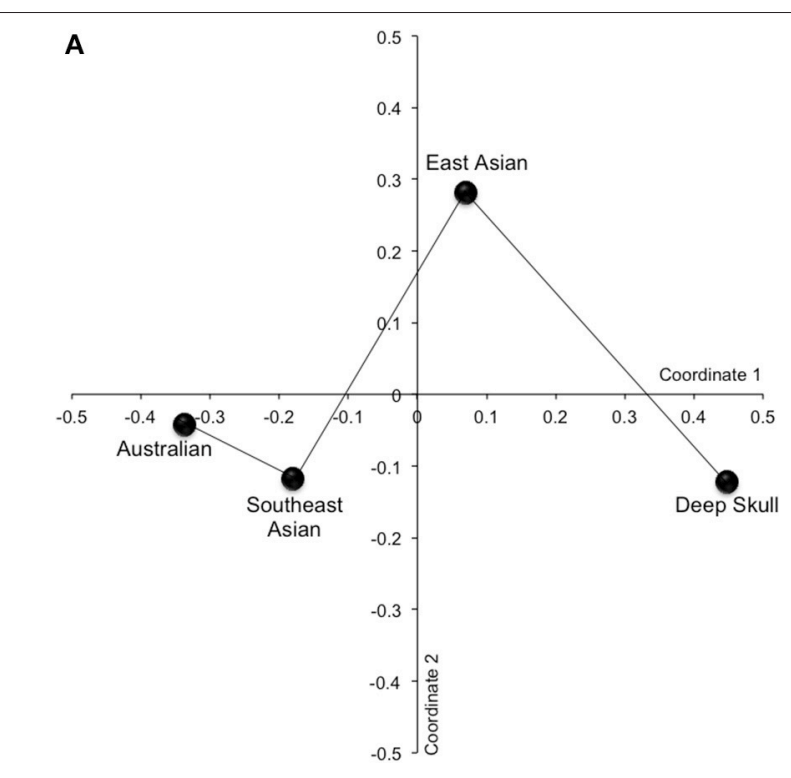

B

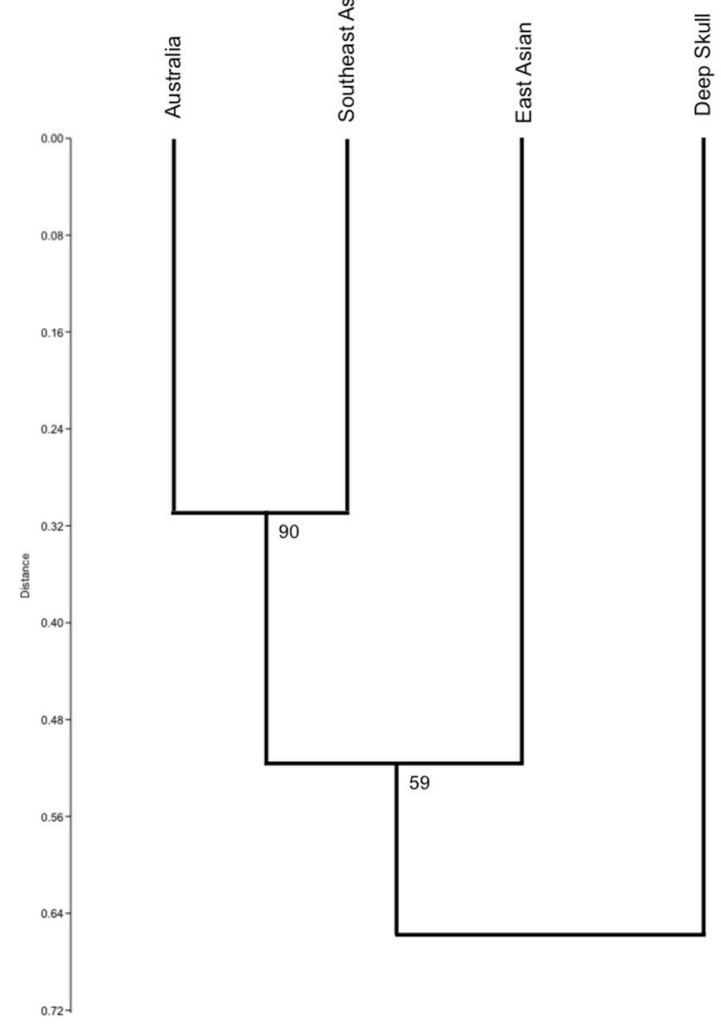

FIGURE 2 | Results of multivariate analysis of 18 continuous and discrete variables. (A) Object plot from principal coordinates analysis (minimum spanning tree indicated) and (B) Dendrogram resulting from UPGMA cluster analysis (bootstrap scores from 100,000 replicates).

\section{Multivariate Analysis}

In Figure 2, we present the results of multivariate analyses using 18 variables and three Pleistocene samples. The analyses used all of the variables in Table 8, except that variables 2 and 4, and variables 6 and 8, were combined. All data for continuous variables were taken from Tables 3-7 (see also, Materials and Methods). The results of principal coordinates analysis (Figure 2A) highlighted a distinction between the Deep Skull and all other samples, although, the minimum spanning tree showed it to be closest to Pleistocene East Asians; although, not especially close to them. The Pleistocene/Early Holocene Australian and Pleistocene Southeast Asian samples were also shown to be phenetically quite close. A dendrogram deriving from UPGMA cluster analysis confirmed the results of principal coordinates analysis, with the Deep Skull branching separately to a cluster containing East Asian, Southeast Asian, and Australian samples (Figure 2B). Furthermore, the Southeast Asian and Australian samples formed a cluster separate to Pleistocene East Asians, with this cluster receiving strong bootstrap support (90\%).

\section{DISCUSSION}

A number of researchers have dismissed the Deep Skull as providing little information of relevance to reconstructing the origins of $\mathrm{AMH}$ in Southeast Asia on account of its poor preservation (e.g., Kamminga and Wright, 1988). We disagree, and while it is incomplete, and its calvaria possesses postburial distortion, careful examination of the specimen reveals the presence of a number of well-preserved morphological features relevant to assessing it affinities. The importance of the specimen stems from the fact that the Deep Skull is the most complete Late Pleistocene specimen recovered from the Niah Caves complex and the oldest $\mathrm{AMH}$ to be recovered from island Southeast Asia (Barker et al., 2013; Hunt and Barker, 2014). Therefore, to overlook it on account of its incomplete preservation, the case with so many ancient remains globally, would be imprudent.

Our studies of the Deep Skull suggest that it most likely represents an adult of advanced age, and is probably also female. The findings are in broad agreement with the published abstract of Birdsell (1978), which also suggested that the Niah individual was an adult, but slightly younger at around 2030 years of age at death. This is important because Brothwell's (1960) diagnosis of the Niah cranium as representing a possible adolescent precluded him and others from undertaking a more comprehensive assessment of its affinities. Moreover, the adult status of a partial femur and tibia recovered by the Harrissons along with the Deep Skull (Harrisson, 1967) adds weight to our diagnosis (Krigbaum and Datan, 2005).

In Table 8 we list and compare 20 morphological features preserved on the Deep Skull with the typical condition seen amongst Late Pleistocene/Early Holocene remains from Southeast Asia, East Asia and Australia. Given the overall fragmentary state of the specimen, this is a surprisingly comprehensive catalog. Of the 20 states shown, the Niah cranium shares only three with Australians, five with Southeast Asians (one unknown) and six with continental East Asians (one unknown). Thus, when compared with these samples it 
TABLE 8 | Comparison of salient features of the Deep Skull with modal states in Pleistocene/Early Holocene samples ${ }^{a}$.

\begin{tabular}{|c|c|c|c|}
\hline Deep Skull & Australian & Southeast Asian & East Asian \\
\hline 1. Vault overall short ${ }^{b}$ & - & - & - \\
\hline 2. Maximum cranial breadth located high on parietals & - & - & - \\
\hline 3. Frontal sagittal ridge absent & + & - & + \\
\hline 4. Excessive width across the parietals, overhanging temporals & - & - & - \\
\hline 5. Vault relatively short \& wide (?brachycephalic) $)^{b}$ & - & - & - \\
\hline 6. Frontal absolutely narrow ${ }^{b}$ & + & - & - \\
\hline 7. Frontal narrow relative to cranial length ${ }^{b}$ & - & + & - \\
\hline 8. Limited post-orbital constriction of frontal & - & - & - \\
\hline 9. Poorly developed glabella & - & - & - \\
\hline 10. Superciliary arches poorly developed & - & - & - \\
\hline 11. Supraorbital trigones poorly developed & - & + & - \\
\hline 12. Strong frontal and parietal bossing & - & - & - \\
\hline 13. Weak or absent cresting, especially weak supramastoid crests and weak/absent occipital crests & - & - & - \\
\hline 14. Thin vault bones (particularly at bregma) & - & - & - \\
\hline 15. Absence of well-developed occipital bun & - & - & + \\
\hline 16. Short mandibular fossa & - & $?$ & $?$ \\
\hline 17. Nasoalveolar clivus short and vertically oriented (low prognathism) & - & + & + \\
\hline 18. Broad piriform aperture & + & + & + \\
\hline 19. Flat mid-face (nasal region) & - & - & + \\
\hline 20. Moderate molar size (buccolingual dimension) & - & + & + \\
\hline
\end{tabular}

aKey: "-" absent, "+" present, and "?" missing/not preserved.

${ }^{b}$ Observation based in part on reconstructed measurement(s) of the Deep Skull.

has few features in common with the Late Pleistocene/Early Holocene inhabitants of this broad region. The results of our multivariate analyses employing 18 of these traits confirm the distinctiveness of the Deep Skull. They also show the individual to be phenetically slightly closer to Pleistocene East Asians than to Southeast Asians or Australians.

One issue that arises from the diagnosis of the Deep Skull as female is the sexually dimorphic nature of the expression of many of its morphological traits. This is not, of course, exclusive to the Deep Skull, but it might explain to some degree the relative gracility of the specimen. A related difficulty in comparing ancient material from across Australia and Southeast/East Asia is that much of it seems to be male, so sex cannot be adequately accounted for in any evaluation of it affinities. However, by including sexbalanced samples from recent populations in morphological and univariate comparisons these concerns were ameliorated to a certain extent in our study. In doing so, we further gained the overall impression that the Deep Skull shows strongest affinities to recent East Asian (sometimes Southeast Asian) populations rather than to New Guinean, Australian or Tasmanian samples. Among all of the measurements we have compared here only two of them are characterized by stronger resemblances to Australians and/or Tasmanians than to other groups.

This is further emphasized when comparing the Deep Skull with a recent Iban cranium and Pleistocene southern Chinese and Australian remains (Figure 3). Noteworthy are its strongly arched vault with prominent bossing, maximum cranial breadth located high on the parietals, absence of a frontal sagittal ridge, excessive width across the parietals, which overhang the temporals, a vault that is relatively short and wide, with limited post-orbital constriction, a weak glabella, poorly developed superciliary ridges and supraorbital trigones, weak or absent cresting especially supramastoid crests and weak/absent occipital crests, absence of a well-developed occipital bun, nasoalveolar clivus that is short and vertically oriented indicating low alveolar prognathism, and a flat midface.

Such a conclusion is further confirmed by comparisons of the Deep Skull's morphology with the detailed characterization of Indigenous Australian crania provided by Larnach and Macintosh (1966, 1970).

In light of the gracility of the Deep Skull and its affinities as suggested by our comparisons, the Niah individual should probably best be considered as belonging to a population broadly related to East Asians that inhabited Borneo during the Late Pleistocene. The evidence at hand suggests there are two most plausible alternatives with respect to its affinities:

(1) The Niah individual samples a population related (?ancestral) to some of the contemporary indigenous people of Borneo (as proposed by Harrisson, 1976).

(2) The Deep Skull represents a Negrito group (see also Birdsell, 1978), and although this term has considerable ambiguity historically in the literature (Endicott, 2013), we apply it in a restricted sense to refer to a gracile and small statured population probably related to the people inhabiting the Philippines today and apparently also during the Pleistocene (Détroit et al., 2013). 

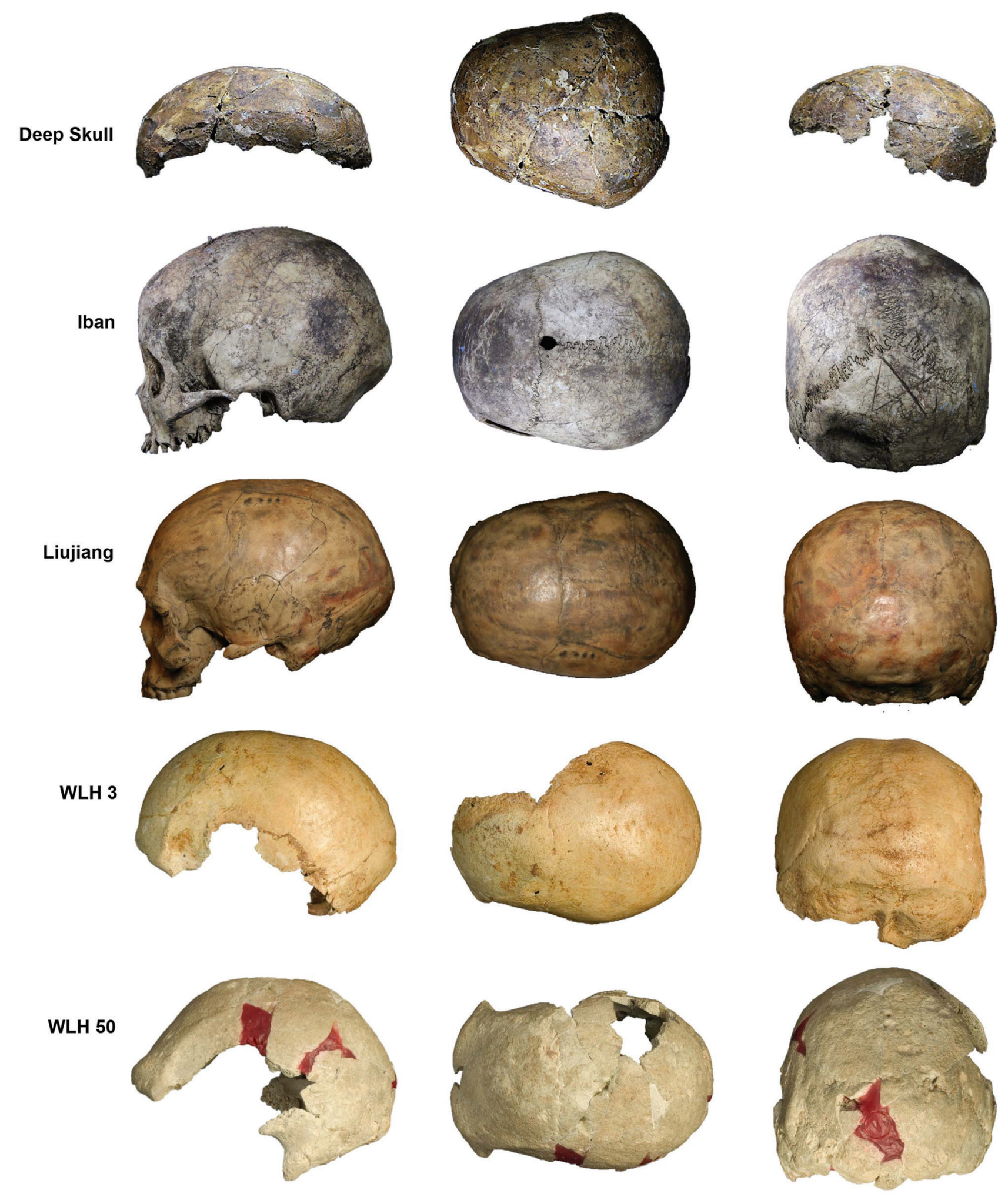

FIGURE 3 | Deep Skull compared with a recent Iban, southern Chinese Pleistocene (Liujiang) and Australian Pleistocene (WLH 3 and WLH 50) crania: left column, left lateral view; middle column, superior view; and right column, posterior view (NB: for ease of comparison, all crania are scaled to the size of the Deep Skull). 


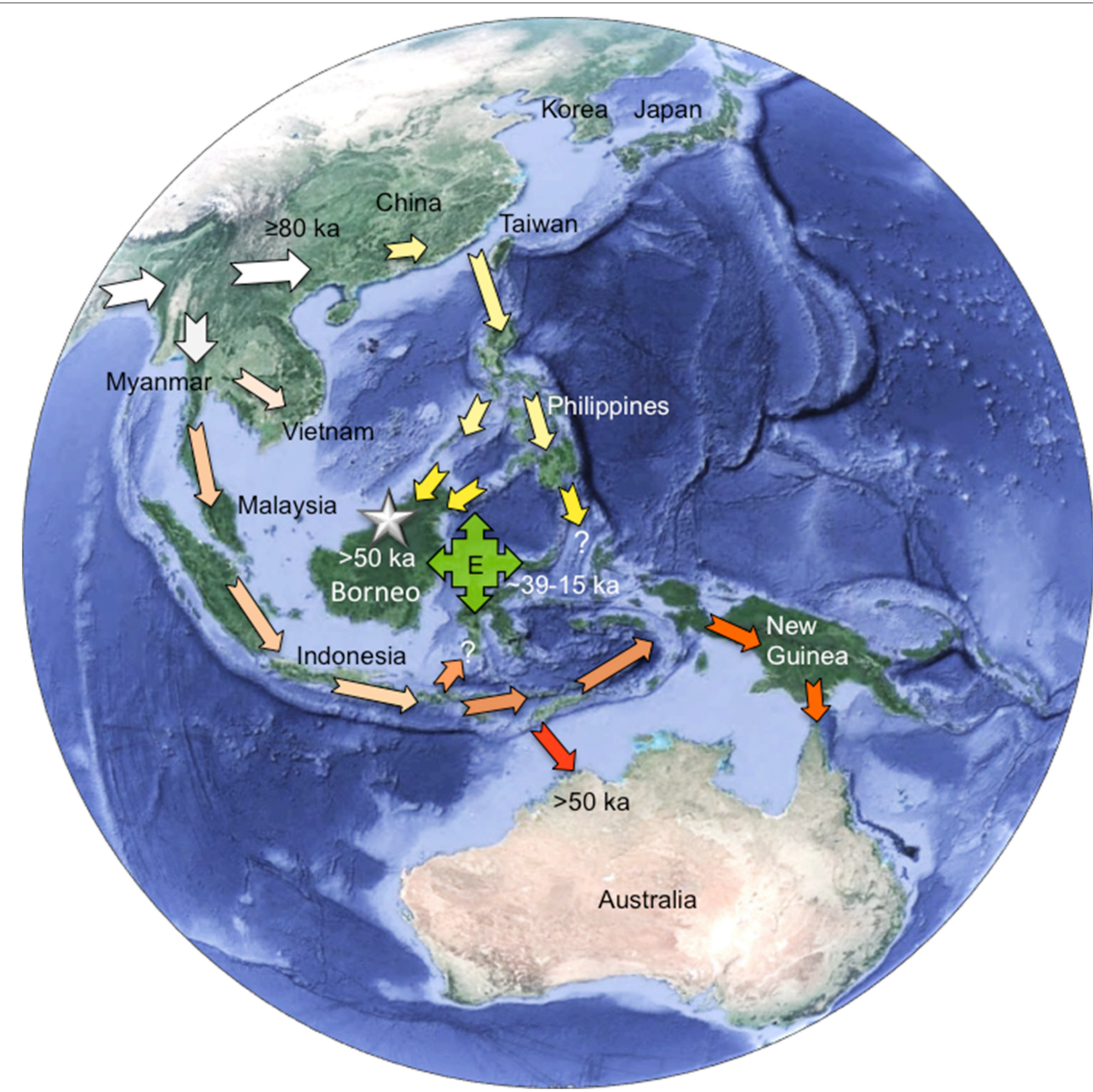

FIGURE 4 | Proposed migrations routes for the Late Pleistocene peopling of Southeast Asia by anatomically modern humans (AMH). (1) earliest AMH arrive from Africa via South Asia into southern China by at least 80 ka (large white arrows); (2) settlement of the East Asian landmass eventually leads to dispersals into the northern oceanic region of southeast Asia through the Philippines and south into Borneo, reaching as far south as Sulawesi and east as Maluku (yellow arrows); (3) another dispersal from the mainland via the Malaysian peninsula establishes the populations of southern archipelago Southeast Asia (light orange arrows), Australia (red arrows) and New Guinea (dark orange arrows); and (4) within Southeast Asia itself the E haplogroup seemingly arose by around 30 ka and was subsequently dispersed by people across much of the region including north into Taiwan and east into New Guinea after $\sim 15$ ka (green box with arrows). (NB: star denotes Niah Cave; map sourced from Google Earth v7.1.5 1557).

Both of these conclusions receive support from the partial femur recovered along with the Deep Skull (Harrisson, 1967), with its short reconstructed length $(\mathrm{c} 370 \mathrm{~mm})$ and diminutive estimated stature (c4.5 feet or c137 cm: Krigbaum and Datan, 2005). Reconstructed stature sits well within the range of contemporary rural female Iban (Strickland and Ulijaszek, 1994), while femur length and presumably stature are within the range of Philippine Negritos (Stock, 2013). However, as no evidence has been found for the Negrito occupation of Borneo, the former of hypothesis seems a more plausible explanation for its affinities at present. 
In Figure 4 we summarize the possible migration routes for the Late Pleistocene peopling of Southeast Asia by $\mathrm{AMH}$ as suggested by the morphological evidence and recent genetic studies of the indigenous people of the region: (1) the earliest $\mathrm{AMH}$ arrived from Africa through South Asia and migrated into southern China by at least $80 \mathrm{ka}$ (large white arrows); (2) settlement of the East Asian landmass eventually led to dispersals into the northern oceanic region of Southeast Asia through the Philippines and south into Borneo, perhaps reaching as far as Sulawesi and Maluku (yellow arrows); (3) another dispersal from mainland Southeast Asia via the Malaysian peninsula established the populations of southern island Southeast Asia (light orange arrows), Australia (red arrows) and New Guinea (dark orange arrows); and (4) within Southeast Asia itself the E haplogroup seemingly arose by around $30 \mathrm{ka}$ and subsequently dispersed across much of the region including east into New Guinea and north into Taiwan after $\sim 15 \mathrm{ka}$.

We note also that genetic studies of recent Southeast Asian populations including Indigenous groups from the Andaman Islands, West Malaysia and the Philippines (Negritos) have demonstrated their close relationship with mainland East Asians (Jinam et al., 2012; Aghakhanian et al., 2015). Moreover, while the Austronesian speaking Indigenous people of Borneo today are suggested to have descended from agriculturalists that settled the area from Taiwan only 4-3 kyr (Bellwood, 1997; Xu et al., 2012), this has been challenged by a wide range of genetic studies covering mtDNA, Y-chromosome and other genomic markers (Capelli et al., 2001; Karafet et al., 2001; Hill et al., 2007; Soares et al., 2008, 2016; Tumonggor et al., 2013; Trejaut et al., 2014). Instead, it seems more likely that Austronesian speakers from Taiwan and island Southeast Asia share a common origin going back to the Late Pleistocene with only a limited signal of the "Out-of-Taiwan" expansion during the Neolithic period. It seems reasonable to opine, therefore, that the Austronesian languages themselves dispersed through island Southeast Asia through small-scale migration and language shift by a Neolithic or even forager-fisher people rather than large-scale migration involving population replacement (Soares et al., 2016).

We propose that the Deep Skull represents the earliest representatives of migration " 2 " in our model (Figure 4). The genetic markers of mainland East Asians are also seen in eastern Indonesia, albeit in combination with some Melanesian haplogroups (Mona et al., 2009), which probably dispersed into the region somewhat later. The estimated geological age of the Deep Skull of c37 ka (Barker et al., 2013; Hunt and Barker, 2014)

\section{REFERENCES}

Aghakhanian, F., Yunus, Y., Naidu, R., Jinam, T., Manica, A., Hoh, B. P., et al. (2015). Unravelling the genetic history of negritos and indigenous populations of Southeast Asia. Genome Biol. Evol. 7, 1206-1215. doi: 10.1093/gbe/evv065

Bae, C. J., Wang, W., Zhao, J., Huang, S., Tian, F., and Shen, G. (2014). Modern human teeth from Late Pleistocene Luna Cave (Guangxi, China). Quat. Int. 354, 169-183. doi: 10.1016/j.quaint.2014.06.051

Barker, G., Barton, H., Bird, M., Daly, P., Datan, I., Dykes, A., et al. (2007). The 'human revolution' in lowland tropical Southeast Asia: the antiquity and also predates molecular clock estimates for the time the Negritos diverged from other East Asian populations around 30-10 ka (Jinam et al., 2012) as well as the estimated divergence time for haplogroup E of $\sim 29.7 \mathrm{ka}$ (Soares et al., 2016). This lends some support also to our conclusion that the Deep Skull may be more closely related to the Indigenous people of Borneo rather than the Negritos of the Philippines.

All of this further suggests that the morphologically robustly built Late Pleistocene people of Southeast and East Asia, widely considered to represent a population related to AustraloMelanesians (e.g., Bellwood, 1997; Matsumura and Hudson, 2005; Matsumura et al., 2008; Oxenham and Buckley, 2016), were probably more restricted in their geographic distribution than has been proposed until now. Our study suggests the twolayer hypothesis is unlikely to apply to the earliest inhabitants of Borneo, in-line with genetic research, and as proposed recently also for Pleistocene human remains described from the Philippines (Détroit et al., 2013).

Our work also highlights some morphological similarities between Pleistocene southern oceanic Southeast Asians and Pleistocene/Early Holocene Australians, consistent with our migration " 3 " scenario (Figure 4) and some genetic research (Mona et al., 2009). In this instance, however, the twolayer hypothesis would have involved a complex mixture of populations originally from mainland East Asia via Borneo and adjacent regions (migration "2": Figure 4), people possessing haplogroup E (migration "4": Figure 4) and possibly people migrating back from New Guinea, rather than later arriving Austronesian speaking agriculturalists. It might better be characterized, therefore, as a complex multi-layer rather than simple two-layer model, in-line with both fossil morphological evidence and genetic data from contemporary indigenous people of the region.

\section{AUTHOR CONTRIBUTIONS}

All authors conceived of the research. DC collected and analyzed the data. DC wrote the manuscript, with critical inputs from all other authors.

\section{ACKNOWLEDGMENTS}

This research was funded primarily by the Australian Research Council under grants FT120100168 (awarded to DC) and LP120200144 (awarded to PT and DC). J. Hum. Evol. 52, 243-261. doi: 10.1016/j.jhevol.2006.08.011

Barker, G., Barton, H., Cole, F., Doherty, C., Gilbertson, D., Hunt, C., et al. (2013). "The Niah Caves, the 'human revolution', and foraging/farming transitions in island Southeast Asia," in Rainforest Foraging and Farming in Island Southeast Asia, Vol. 1, the Archaeology of the Niah caves, Sarawak, ed G. Barker (Cambridge: McDonald Institute for Archaeological Research), 341-367.

Bassed, R. B., Briggs, C., and Drummer, O. H. (2010). Analysis of time of closure of the spheno-occipital synchondrosis using computed tomography. Forensic Sci. Int. 200, 161-164. doi: 10.1016/j.forsciint.2010.04.009 
Bellwood, P. (1997). Prehistory of the Indo-Malaysian Archipelago, Revised Edition. Honolulu: University of Hawai'i Press.

Birdsell, J. B. (1978). A reassessment of the age, sex and population affinities of the Niah cranium. Am. J. Phys. Anthropol. 50, 419.

Brothwell, D. R. (1960). Upper Pleistocene human skull from Niah Caves, Sarawak. Sarawak Mus. J. 9, 323-349.

Brown, P. (1989). Coobool Creek. Canberra: Terra Australis 13, Department of Prehistory, Research School of Pacific Studies, The Australian National University.

Brown, P. (2015). Metric data for Pleistocene/Early Holocene Australian, Neolithic Chinese and Recent Chinese Skulls. Available online at: http://www.peterbrownpalaeoanthropology.net/resource.html (Accessed October 2015).

Buikstra, J. E., and Ubelaker, D. H. (1994). Standards for Data Collection from Human Skeletal Remains: Proceedings of a Seminar at the Field Museum of Natural History (Arkansas Archaeology Research Series 44). Lafayette: Fayetteville Arkansas Archaeological Survey.

Bulbeck, D. (2005). "The Late Glacial Maximum human burial from Liang Lemdubu in northern Sahulland," in The Archaeology of the Aru Islands, Eastern Indonesia, Terra Australis 22, eds S. O'Connor, M. Spriggs, and P. Veth (Canberra: Pandanus Press), 255-294.

Capelli, C., Wilson, J. F., Richards, M., Stumpf, M. P., Gratrix, F., Oppenheimer, S., et al. (2001). A predominantly indigenous paternal heritage for the Austronesian-speaking peoples of insular Southeast Asia and Oceania. Am. J. Hum. Genet. 68, 432-443. doi: 10.1086/318205

Cho, B. H., and Jung, Y. H. (2012). Osteoarthritic changes and condylar positioning of the temporomandibular joint in Korean children and adolescents. Imaging Sci. Dent. 42, 169-174. doi: 10.5624/isd.2012.42.3.169

Coon, C. S. (1962). The Origin of Races. New York, NY: Knopf.

Cuong, N. L. (1986). Two early Hoabinhian crania from Thanh Hoa province, Vietnam. Z. Morphol. Anthropol. 77, 11-17.

Curnoe, D., Ji, X., Shaojin, H., Taçon, P. S., and Li, Y. (2016). Dental remains from Longtanshan cave 1 (Yunnan, China), and the initial presence of anatomically modern humans in East Asia. Quat. Int. 400, 180-186. doi: 10.1016/j.quaint.2015.05.057

Curnoe, D., and Thorne, A. (2006). Human origins in Australia: the skeletal evidence. Before Farming 2006, 1-28. doi: 10.3828/bfarm.2006.1.5

Demeter, F., Shackelford, L. L., Bacon, A. M., Duringere, P., Westaway, K., Sayavongkhamdy, T., et al. (2012). Anatomically modern human in Southeast Asia (Laos) by 46 ka. Proc. Natl. Acad. Sci. U.S.A. 109, 14375-11438. doi: 10.1073/pnas. 1208104109

Détroit, F., Corny, J., Dizon, E. Z., and Mijares, A. S. (2013). "Small size" in the Philippine human fossil record: is it meaningful for a better understanding of the evolutionary history of the negritos? Hum. Biol. 85, 45-66. doi: 10.3378/027.085.0303

Détroit, F., Dizon, E., Falguères, C., Hameau, S., Ronquillo, W., and Sémah, F. (2004). Upper Pleistocene Homo sapiens from the Tabon cave (Palawan, The Philippines): description and dating of new discoveries. C. R. Palevol 3, 705-712. doi: 10.1016/j.crpv.2004.06.004

Dizon, E., Détroit, F., Sémah, F., Falguères, C., Hameau, S., Ronquillo, W., et al. (2002). Notes on the morphology and age of the Tabon Cave fossil Homo sapiens. Curr. Anthropol. 43, 660-666. doi: 10.1086/342432

Ekizoglu, O., Hocaoglu, E., Can, I. O., Inci, E., Aksoy, S., and Sayin, I. (2016). Spheno-occipital synchondrosis fusion degree as a method to estimate age: a preliminary, magnetic resonance imaging study. Aust. J. Forensic Sci. 48, 159-170. doi: 10.1080/00450618.2015.1042047

Endicott, P. (2013). Introduction: revisiting the "negrito" hypothesis: a transdisciplinary approach to human prehistory in Southeast Asia. Hum. Biol. 85, 7-20. doi: 10.3378/027.085.0301

Green, H., and Curnoe, D. (2005). Mandibular fossa of fossil Australians. Homo J. Comp. Hum. Biol. 56, 233-247. doi: 10.1016/j.jchb.2005.06.001

Hammer, Ø., Harper, D. A. T., and Ryan, P. D. (2001). PAST: Paleontological Statistics Software Package for education and data analysis. Palaeontol. Electron. 4, 9.

Harrisson, B. (1967). A classification of stone age burials from Niah Cave, Sarawak. SNIJ 15, 126-200.

Harrisson, T. (1976). "The Upper Palaeolithic in Malaysia (Malaya and Borneo) and adjacent areas: gateway to the Pacific," in IXe Congres, Union Internationale des Sciences Prehistoriques et Protohistoriques (Nice), Colloque 18, 12-27.
Hill, C., Soares, P., Mormina, M., Macaulay, V., Clarke, D., Blumbach, P. B., et al. (2007). A mitochondrial stratigraphy for island southeast Asia. Am. J. Hum. Genet. 80, 29-43. doi: 10.1086/510412

Hillson, S. (1996). Dental Anthropology. Cambridge: Cambridge University Press.

Hooijer, D. A. (1950). Fossil evidence of Austromelanesian migrations in Malaysia? Southwest. J. Anthropol. 1950, 416-422. doi: 10.1086/soutjanth.6.4.36 28568

Howells, W. W. (1996). Howell's craniometric data on the internet. Am. J. Phys. Anthropol. 101, 441-442. doi: 10.1002/ajpa.1331010302

Hunt, C., and Barker, G. (2014). "Missing links, cultural modernity and the dead: anatomically modern humans in the Great Cave of Niah (Sarawak, Borneo)," in Southern Asia, Australia, and the Search for Human Origins, eds R. Dennell and M. Porr (Cambridge: Cambridge University Press), 90-107.

Jacob, T. (1967). Some Problems Pertaining to the Racial History of the Indonesian Region. Utrecht: Drukkerij Neerlandia.

Jacob, T. (1968). A human wadjakoid maxillary fragment from China. Proc. K. Ned. Akad. B 71, 232e235.

Jinam, T., Lih-Chun Hong, A., Phipps, M. E., Stoneking, M., and Ameen, M. (2012). Evolutionary history of continental Southeast Asians: 'Early Train' hypothesis based on genetic analysis of mitochondrial and autosomal DNA data. Mol. Biol. Evol. 29, 3513-3527. doi: 10.1093/molbev/mss169

Kaifu, Y., Fujita, M., Kono, R. T., and Baba, H. (2011). Late Pleistocene modern human mandibles from the Minatogawa Fissure site, Okinawa, Japan: morphological affinities and implications for modern human dispersals in East Asia. Anthropol. Sci. 119, 137-157. doi: 10.1537/ase.090424

Kamminga, J., and Wright, R. V. S. (1988). The Upper Cave at Zhoukoudian and the origins of the Mongoloids. J. Hum. Evol. 17, 739-767. doi: 10.1016/00472484(88)90064-4

Karafet, T., Xu, L., Du, R., Wang, W., Feng, S., Wells, R. S., et al. (2001). Paternal population history of East Asia: sources, patterns, and microevolutionary processes. Am. J. Hum. Genet. 69, 615-628. doi: 10.1086/323299

Kennedy, K. A. R. (1977). The deep skull of Niah: an assessment of twenty years of speculation concerning its evolutionary significance. Asian Perspect. 20, 32-50.

Krigbaum, J., and Datan, I. (2005). "The deep skull and associated human remains from Niah Cave," in The Perak Man and other Prehistoric Skeletons of Malaysia, ed Z. Majid (Pulau Penang: Universiti sains Malaysia), 131-154.

Krigbaum, J., and Manser, J. (2005). "The West Mouth burial series from Niah Cave: past and present," in The Perak Man and Other Prehistoric Skeletons of Malaysia, ed Z. Majid (Pulau Penang: Universiti sains Malaysia), 175-206.

Larnach, S. L., and Macintosh, N. W. G. (1966). The Craniology of the Aborigines of Coastal New South Wales. Oceania Monographs No 13. Sydney: University of Sydney.

Larnach, S. L., and Macintosh, N. W. G. (1970). The Craniology of the Aborigines of Queensland. The Oceania Monographs No. 15. Sydney: University of Sydney.

Liu, W., Martinón-Torres, M., Cai, Y. J., Xing, S., Tong, H. W., Pei, S. W., et al. (2015). The earliest unequivocally modern humans in southern China. Nature 526, 696-699. doi: 10.1038/nature15696

Lovejoy, C. O. (1985). Dental wear in the Libben population: its functional pattern and role in the determination of adult skeletal age at death. Am. J. Phys. Anthropol. 68, 47-56. doi: 10.1002/ajpa.1330680105

Macintosh, N. W. G. (1965). "The physical aspect of man in Australia," in Aboriginal Man in Australia, eds R. M. Berndt and C. H. Berndt (Sydney: Angus and Robertson), 29-70.

Matsumura, H., Cuong, N. L., Thuy, N. K., and Anezaki, T. (2001). Dental morphology of the Early Hoabinian, the Neolithic Da But and the Metal Age Dong Son civilized peoples in Vietnam. Z. Morphol. Anthropol. 83, 59-73.

Matsumura, H., and Hudson, M. J. (2005). Dental perspectives on the population history of Southeast Asia. Am. J. Phys. Anthropol. 127, 182-209. doi: 10.1002/ajpa.20067

Matsumura, H., and Pookajorn, S. (2005). A morphometric analysis of the Late Pleistocene Human Skeleton from the Moh Khiew Cave in Thailand. Homo J. Comp. Hum. Biol. 56, 93-118. doi: 10.1016/j.jchb.2005.05.004

Matsumura, H., Yoneda, M., Dodo, Y., Oxenham, M. F., Cuong, N. L., Thuy, N. K., et al. (2008). Terminal Pleistocene human skeleton from Hang Cho Cave, northern Vietnam: implications for the biological affinities of Hoabinhian people. Anthropol. Sci. 116, 201-217. doi: 10.1537/ase.070416 
Matsumura, H., and Zuraina, M. (1999). Metric Analyses of an Early Holocene human skeleton from Gua Gunung Runtuh, Malaysia. Am. J. Phys. Anthropol. 109, 327-340.

Meindel, R. S., and Lovejoy, C. O. (1985). Ectocranial suture closure: a revised method for the determination of skeletal age at death and blind tests of its accuracy. Am. J. Phys. Anthropol. 68, 57-66. doi: 10.1002/ajpa.1330680106

Mijares, A. S., Détroit, F., Piper, P., Grün, R., Bellwood, P., Aubert, M., et al. (2010). New evidence for a 67,000-year-old human presence at Callao Cave, Luzon, Philippines. J. Hum. Evol. 59, 123-132. doi: 10.1016/j.jhevol.2010.04.008

Mona, S., Grunz, K. E., Brauer, S., Pakendorf, B., Castrì, L., Sudoyo, H., et al. (2009). Genetic admixture history of Eastern Indonesia as revealed by Ychromosome and mitochondrial DNA analysis. Mol. Biol. Evol. 26, 1865-1877. doi: 10.1093/molbev/msp097

Mulvaney, D. J. (1958). The Australian Aborigines 1606-1929: opinion and fieldwork. Aust. Hist. Stud. 8, 131-151.

Mulvaney, D. J. (1966). Fact, fantasy and Aboriginal Australian ethnic origins. Mankind 6, 299-305.

Olley, J. M., Roberts, R. G., Yoshida, H., and Bowler, J. M. (2006). Singlegrain optical dating of grave-infill associated with human burials at Lake Mungo, Australia. Quat. Sci. Rev. 25, 2469-2474. doi: 10.1016/j.quascirev.2005. 07.022

Oxenham, M., and Buckley, H. R. (2016). "The population history of mainland and island Southeast Asia," in The Routledge Handbook of Bioarchaeology in Southeast Asia and the Pacific Islands, eds M. Oxenham and H. Buckley (New York, NY: Routledge), 9-23.

Presser, J. C., Stoneking, M., and Redd, A. J. (2002). Tasmanian aborigines and DNA. Pap. Proc. R. Soc. Tasma. 136, 35-38.

Smith, B. H. (1984). Patterns of molar wear in hunter-gatherers and agriculturalists. Am. J. Phys. Anthropol. 63, 39-56. doi: 10.1002/ajpa.1330630107

Soares, P. A., Trejaut, J. A., Rito, T., Cavadas, B., Hill, C., Eng, K. K., et al. (2016). Resolving the ancestry of Austronesian-speaking populations. Hum. Genet. 135, 309-326. doi: 10.1007/s00439-015-1620-z

Soares, P., Trejaut, J. A., Loo, J. H., Hill, C., Mormina, M., Lee, C. L., et al. (2008). Climate change and postglacial human dispersals in Southeast Asia. Mol. Biol. Evol. 25, 1209-1218. doi: 10.1093/molbev/msn068

Stock, J. T. (2013). The skeletal phenotype of "Negritos" from the Andaman Islands and Philippines relative to global variation among hunter-gatherers. Hum. Biol. 85, 67-94. doi: 10.3378/027.085.0304

Storm, P. (1995). The Evolutionary Significance of the Wajak Skulls. Netherlands: National Naturhistorisch Museum.

Storm, P., Wood, R., Stringer, C., Bartsiokas, A., de Vos, J., Aubert, M., et al. (2013). $\mathrm{U}$-series and radiocarbon analyses of human and faunal remains from Wajak, Indonesia. J. Hum. Evol. 64, 356-365. doi: 10.1016/j.jhevol.2012.11.002

Strickland, S. S., and Ulijaszek, S. J. (1994). Body mass index and illness in rural Sarawak. Eur. J. Clin. Nutr. 48, S98-S109.

Suzuki, H., and Hanihara, K. (eds.). (1982). The Minatogawa Man: The Upper Pleistocene Man from the Island of Okinawa (No. 19). Tokyo: University of Tokyo Press.

Thorne, A., Grün, R., Mortimer, G., Spooner, N. A., Simpson, J. J., McCulloch, M., et al. (1999). Australia's oldest human remains: age of the Lake
Mungo 3 skeleton. J. Hum. Evol. 36, 591-612. doi: 10.1006/jhev.199 9.0305

Trejaut, J. A., Poloni, E. S., Yen, J. C., Lai, Y. H., Loo, J. H., Lee, C. L., et al. (2014). Taiwan Y-chromosomal DNA variation and its relationship with Island Southeast Asia. BMC Genet. 15:77. doi: 10.1186/1471-215 6-15-77

Tumonggor, M. K., Karafet, T. M., Hallmark, B., Lansing, J. S., Sudoyo, H., Hammer, M. F., et al. (2013). The Indonesian archipelago: an ancient genetic highway linking Asia and the Pacific. J. Hum. Genet. 58, 165-173. doi: 10.1038/jhg.2012.154

Turner, C. G., and Eder, J. F. (2006). "Dentition of the Batak people of Palawan Island, the Philippines: Souheast Asian negrito origins," in Bioarchaeology of Southeast Asia, eds M. Oxenham and N. Tayles (Cambridge: Cambridge University Press), 172-187.

van Stein Callenfels, P. V. (1936). The Melanesoid civilizations of Eastern Asia. Bull Raffles Mus. Soc. B 1, 41-51.

Von Bonin, G. (1931). Beitrag zur kraniologie von Ost-Asien. Biometrika 23, 52-113. doi: 10.1093/biomet/23.1-2.52

Von Koenigswald, G. H. R. (1952). Evidence of a prehistoric Australomelanesoid population in Malaya and Indonesia. Southwest. J. Anthropol. 8, 92-96. doi: 10.1086/soutjanth.8.1.3628557

Wolpoff, M. H. (1999). Paleoanthropology, 2nd Edn. Boston, MA: McGraw-Hill.

Wu, X. (1987). Relation between Upper Paleolithic men in China and their southern neighbors in Niah and Tabon. Acta Anthropol. Sin. 6, $180-183$.

$\mathrm{Wu}, \mathrm{X}$. (1992). "The origin and dispersal of anatomically modern humans in East and Southeast Asia," in The Evolution and Dispersal of Modern Humans in Asia, eds T. Akazawa, K. Aoki, and T. Kimura (Tokyo: Hokusensha), 373-378.

Wu, X., and Poirier, F. E. (1995). Human Evolution in China. New York, NY: Oxford University Press.

Xiao, D., Bae, C. J., Shen, G., Delson, E., Jin, E. J. H., Webb, N. M., et al. (2014). Metric and geometric morphometric analysis of new hominin fossils from Maba (Guangdong, China). J. Hum. Evol. 74, 1-20. doi: 10.1016/j.jhevol.2014.04.003

Xu, S., Pugach, I., Stoneking, M., Kayser, M., and Jin, L. (2012). Genetic dating indicates that the Asian-Papuan admixture through Eastern Indonesia corresponds to the Austronesian expansion. Proc. Natl. Acad. Sci. U.S.A. 109, 4574-4579. doi: 10.1073/pnas.1118892109

Conflict of Interest Statement: The authors declare that the research was conducted in the absence of any commercial or financial relationships that could be construed as a potential conflict of interest.

Copyright (C) 2016 Curnoe, Datan, Taçon, Leh Moi Ung and Sauffi. This is an openaccess article distributed under the terms of the Creative Commons Attribution License (CC BY). The use, distribution or reproduction in other forums is permitted, provided the original author(s) or licensor are credited and that the original publication in this journal is cited, in accordance with accepted academic practice. No use, distribution or reproduction is permitted which does not comply with these terms. 